\title{
Transition Metal Substitution Effects on Metal-to-Polyoxometalate Charge Transfer
}

Elliot N. Glass, ${ }^{a}$ John Fielden, ${ }^{a, b, c}$ Zhuangqun Huang, ${ }^{a}$ Xu Xiang, ${ }^{a, d}$ Djamaladdin G. Musaev, ${ }^{a}$ Tianquan Lian, ${ }^{a}$ Craig L. Hill ${ }^{* a}$

${ }^{a}$ Department of Chemistry and Cherry L. Emerson Center for Scientific Computation, Emory University, Atlanta, Georgia 30322, United States

${ }^{b}$ WestCHEM, School of Chemistry, University of Glasgow, Glasgow G12 8QQ, United Kingdom

${ }^{c}$ School of Chemistry, University of East Anglia, Norwich NR4 7TJ, United Kingdom

${ }^{d}$ State Key Laboratory of Chemical Resource Engineering, Beijing University of Chemical Technology, Beijing 100029, P. R. China

\begin{abstract}
A series of heterobimetallic transition metal substituted polyoxometalates (TMSPs) have been synthesized based on the $\mathrm{Co}^{\mathrm{II}}$-centered ligand $\left[\mathrm{Co}^{\mathrm{II}} \mathrm{W}_{11} \mathrm{O}_{39}\right]^{10-}$. The eight complex series, $\left[\mathrm{Co}^{\mathrm{II}}\left(\mathrm{M}^{\mathrm{x}} \mathrm{OH}_{\mathrm{y}}\right) \mathrm{W}_{11} \mathrm{O}_{39}\right]^{(12-\mathrm{x}-\mathrm{y})-}\left(\mathrm{M}^{\mathrm{x}} \mathrm{OH}_{\mathrm{y}}=\mathrm{V}^{\mathrm{IV}} \mathrm{O}, \mathrm{Cr}^{\mathrm{III}}\left(\mathrm{OH}_{2}\right), \mathrm{Mn}^{\mathrm{II}}\left(\mathrm{OH}_{2}\right), \mathrm{Fe}^{\mathrm{III}}\left(\mathrm{OH}_{2}\right), \mathrm{Co}^{\mathrm{II}}\left(\mathrm{OH}_{2}\right), \mathrm{Ni}^{\mathrm{II}}\left(\mathrm{OH}_{2}\right)\right.$, $\left.\mathrm{Cu}^{\mathrm{II}}\left(\mathrm{OH}_{2}\right), \mathrm{Zn}^{\mathrm{II}}\left(\mathrm{OH}_{2}\right)\right)$, of which six are reported for the first time, was synthesized starting from $\left[\mathrm{Co}^{\mathrm{III}} \mathrm{W}_{11} \mathrm{O}_{39}\right]^{9-}$ and studied using spectroscopic, electrochemical, and computational techniques to evaluate the influence of substituted transition metals on the photodynamics of the metal-topolyoxometalate charge transfer (MPCT) transition. The bimetallic complexes all show higher visible light absorption than the plenary $\left[\mathrm{Co}^{\mathrm{II}} \mathrm{W}_{12} \mathrm{O}_{40}\right]^{6-}$ and demonstrate the same MPCT transition as the plenary complex, but have shorter excited state lifetimes (sub-300 ps in aqueous media). The decreased lifetimes are rationalized on the basis of nonradiative relaxation due to coordinating aqua ligands, increased interaction with cations due to increased negative charge, and the energy gap law, with the strongest single factor appearing to be the charge on the anion. The most promising results are from the $\mathrm{Cr}$ - and $\mathrm{Fe}$ substituted systems, which retain excited state lifetimes at least $50 \%$ of that of $\left[\mathrm{Co}^{\mathrm{II}} \mathrm{W}_{12} \mathrm{O}_{40}\right]^{6-}$ while more than tripling the absorbance at $400 \mathrm{~nm}$.
\end{abstract}

\section{Introduction}

Molecular charge transfer (CT) chromophores are relevant to conversion of sunlight into electrical energy ${ }^{1-3}$ or chemical fuels, ${ }^{4-13}$ as photocatalysts for other chemical transformations, ${ }^{14,15}$ and a wide range of photonic applications (e.g. non-linear optics, ${ }^{16-18}$ photo- and electroluminescence, ${ }^{19-21}$ sensing ${ }^{22,23}$ ). The vast majority of these molecular CT systems are organic, or metal-organic in nature, and compared to solid state inorganic semiconductors they can offer advantages in cost, synthetic versatility for tailoring properties, and processability. However, they are typically more vulnerable to photo- and other degradation processes than semiconductors, particularly if used to drive demanding photo-redox chemistry such as light driven water oxidation. ${ }^{24}$ Development of robust, molecular, all-inorganic CT chromophores is therefore a highly desirable goal, as these could combine the stability of solid-state materials with many of the advantages of molecular organic and metal-organic systems.

To this end, chromophores composed of heterobimetallic groups have recently attracted interest as possible replacements for organic/metal-organic photosensitizers in photocatalytic solar fuel production. In these materials, a donor and an acceptor transition metal are bound by an oxido group to form a 
chromophoric unit in which light absorption generates metal-to-metal charge transfer (MMCT) excited states and metal oxidation states conducive to catalysis. ${ }^{25-35}$ These units have been shown to act as photocatalysts for multi-electron processes, including $\mathrm{CO}_{2}$ reduction ${ }^{25}$ and water oxidation. ${ }^{27}$ MMCT chromophores thus represent a new class of materials that avoid some of the pitfalls of traditional organic photosensitizers and metal oxide semiconductors. However, the only molecular example so far is supported by organic ligands. ${ }^{35}$

We are investigating polyoxometalates (POMs), a broad class of molecular metal oxide structures, as the basis for molecular all-inorganic MMCT or metal-to-polyoxometalate (MPCT) chromophores. As molecular species, these complexes combine the advantages of molecular characterization and controlled synthesis with the robustness of all-inorganic metal oxide semiconductors and substrates. Previously, we showed that coordination of Re carbonyls, or lone pair donors $\left(\mathrm{Sn}^{\mathrm{II}} / \mathrm{Sb}^{\mathrm{III}}\right)$ to POMs resulted in strong visible MPCT-based absorptions, but excited state lifetimes were too short (2 to $66 \mathrm{ps)} \mathrm{to} \mathrm{be} \mathrm{of} \mathrm{use} \mathrm{in}$ solution photochemistry. ${ }^{36-40}$ At the same time, our systematic investigation of a series of four cobaltcontaining Keggin POMs, found one complex, cobalt-centered $\left[\mathrm{Co}^{\mathrm{II}} \mathrm{W}_{12} \mathrm{O}_{40}\right]^{6-}$, with a much longer intramolecular MPCT excited state lifetime (1.7 ns in $\mathrm{MeCN}, 420 \mathrm{ps}$ in $\mathrm{H}_{2} \mathrm{O}$ ) but much weaker visible light absorption. ${ }^{41}$ Analogous to other MMCT chromophores, photoexcitation of the MPCT transition in $\left[\mathrm{Co}^{\mathrm{II}} \mathrm{W}_{12} \mathrm{O}_{40}\right]^{6-}$ forms transient $\mathrm{Co}^{\mathrm{III}}\left(\mathrm{E}^{\circ}=c a .+1.1 \mathrm{~V}\right.$ vs. NHE$)$ and reduced polytungstate $\left(\mathrm{E}^{\circ}=c a .-0.3\right.$ vs. NHE) species with potentials suitable for various electron transfer reactions. Here, we report the rational synthesis of a series of heterobimetallic transition metal-substituted polyoxometalates (TMSPs) to systematically investigate the effect of 3d-transition metal substitution on the light absorption properties and excited state dynamics of the cobalt-centered Keggin system. A series of eight TMSP complexes $\left[\mathrm{Co}^{\mathrm{II}}\left(\mathrm{M}^{\mathrm{x}} \mathrm{OH}_{\mathrm{y}}\right) \mathrm{W}_{11} \mathrm{O}_{39}\right]^{(12-\mathrm{x}-\mathrm{y})-}\left(\mathrm{M}^{\mathrm{x}} \mathrm{OH}_{\mathrm{y}}=\mathrm{V}^{\mathrm{IV}} \mathrm{O}, \mathrm{Cr}^{\mathrm{III}}\left(\mathrm{OH}_{2}\right), \mathrm{Mn}^{\mathrm{II}}\left(\mathrm{OH}_{2}\right), \mathrm{Fe}^{\mathrm{III}}\left(\mathrm{OH}_{2}\right), \mathrm{Co}^{\mathrm{II}}\left(\mathrm{OH}_{2}\right), \mathrm{Ni}^{\mathrm{II}}\left(\mathrm{OH}_{2}\right)\right.$, $\left.\mathrm{Cu}^{\mathrm{II}}\left(\mathrm{OH}_{2}\right), \mathrm{Zn}^{\mathrm{II}}\left(\mathrm{OH}_{2}\right)\right)$, of which six $\left(\mathrm{M}^{\mathrm{x}} \mathrm{OH}_{\mathrm{y}}=\mathrm{Cr}^{\mathrm{III}}\left(\mathrm{OH}_{2}\right), \mathrm{Mn}^{\mathrm{II}}\left(\mathrm{OH}_{2}\right), \mathrm{Fe}^{\mathrm{III}}\left(\mathrm{OH}_{2}\right), \mathrm{Ni}^{\mathrm{II}}\left(\mathrm{OH}_{2}\right), \mathrm{Cu}^{\mathrm{II}}\left(\mathrm{OH}_{2}\right)\right.$, $\left.\mathrm{Zn}^{\mathrm{II}}\left(\mathrm{OH}_{2}\right)\right)$ are reported for the first time, were compared to the parent complex using spectroscopic, electrochemical, and computational techniques. The results show that, while charge-transfer (CT) excited state lifetimes decrease significantly compared to $\left[\mathrm{Co}^{\mathrm{II}} \mathrm{W}_{12} \mathrm{O}_{40}\right]^{6-}$, visible light absorption increases across the entire series and the CT lifetimes (up to 270 ps to $\mathrm{H}_{2} \mathrm{O}$ ) are still longer than those of other molecular MPCT and lone-pair-to-POM CT systems. ${ }^{36-40}$

\section{Experimental Section}

General Methods and Materials. All reagents were purchased as ACS analytical or reagent grade and used as received. Syntheses were carried out in the ambient atmosphere. The identities and purities of all synthesized compounds were confirmed by infrared and UV-visible spectroscopy. Infrared spectra (2\% by weight in KBr) were recorded on a Thermo Nicolet 6700 FT-IR spectrometer. Static electronic absorption spectra were acquired using an Agilent 8453 spectrophotometer equipped with a diode-array detector and Agilent 89090A cell temperature controller unit. Elemental analyses were performed by Galbraith Laboratories, Inc. (Knoxville, Tennessee). Thermogravimetric analyses (Figures S10 and S11) were acquired on a Perkin Elmer STA 6000 analyzer. Cyclic voltammograms were recorded on a Pine Research Instruments WaveDriver 20 bipotentiostat using a standard three-electrode setup equipped with a glassy-carbon working electrode, a platinum wire auxiliary electrode and an $\mathrm{Ag} / \mathrm{AgCl}(1 \mathrm{M} \mathrm{KCl}) \mathrm{BAS}$ reference electrode, using potassium acetate $(0.500 \mathrm{M}, \mathrm{pH} 5)$ as the buffer/electrolyte. All redox potentials are reported relative to this reference electrode $(\sim+235 \mathrm{mV}$ nominal difference between NHE and the BAS electrode). 
$\mathrm{K}_{\mathbf{5}} \mathrm{H}\left[\mathrm{Co}^{\mathrm{II}} \mathbf{W}_{12} \mathrm{O}_{40}\right] \cdot \mathbf{1 2 H}_{2} \mathrm{O}\left(\mathrm{Co}^{\mathrm{II}} \mathbf{W}_{\mathbf{1 2}}\right)$. The synthesis was adapted from published methods. ${ }^{41-44}$ Sodium tungstate dihydrate $(19.8 \mathrm{~g}, 60 \mathrm{mmol})$ was dissolved with stirring in $40 \mathrm{~mL}$ of deionized water, after which the $\mathrm{pH}$ was adjusted to 7.0 using glacial acetic acid. A separate solution of cobalt(II) acetate tetrahydrate $(2.5 \mathrm{~g}, 10 \mathrm{mmol})$ in $12 \mathrm{~mL}$ deionized water was prepared, with the $\mathrm{pH}$ adjusted to $c a .7$ by the addition of a few drops of glacial acetic acid. Both solutions were heated with stirring until near boiling, and the cobalt(II) acetate solution was added to the sodium tungstate solution slowly, yielding a dark green solution. The mixture was boiled for 20 minutes and filtered hot. A $20 \mathrm{~mL}$ saturated solution of potassium acetate adjusted to $\mathrm{pH} 7.0$ by the addition of glacial acetic acid was prepared while the filtrate was reheated. The potassium acetate solution was added slowly to the filtrate with stirring, precipitating a green solid. The resulting mixture was allowed to cool to room temperature and filtered, rinsing the solid twice with the filtrate. The solid was redissolved in $40 \mathrm{~mL} 2 \mathrm{M}$ sulfuric acid with stirring and gentle heating for 15 minutes, yielding a dark blue solution. Insoluble material was removed by filtration. The solution volume was reduced by half through gentle heating, then allowed to develop crystals via slow evaporation. The dark blue crystals collected from the mother liquor were further purified by passing a concentrated solution through Dowex 50WX8 ion-exchange resin conditioned in the $\mathrm{K}^{+}$cycle, removing a large excess of latent cobalt cations. The eluent was evaporated to dryness using a rotary evaporator, dissolved in minimal $1 \mathrm{M} \mathrm{HCl}$ and allowed to develop crystals of $\mathbf{C o}^{\mathbf{I I}} \mathbf{W}_{\mathbf{1 2}}$ via slow evaporation. Yield: $3.82 \mathrm{~g}$ (21.9\% based on W). FTIR (2\% KBr pellet), v, cm ${ }^{-1}: 943$ (s), 889 (s), 871 (sh), 739 (s), $692(\mathrm{sh}), 580(\mathrm{w}), 449(\mathrm{~m})$. UV-vis $\left(\mathrm{H}_{2} \mathrm{O}\right), \lambda_{\max }, \mathrm{nm}\left(\varepsilon, \mathrm{L} \mathrm{mol}^{-1} \mathrm{~cm}^{-1}\right): 625$ (223). Elemental analysis: calcd. (found) for $\mathrm{K}_{5} \mathrm{Co}_{1} \mathrm{~W}_{12} \mathrm{O}_{52} \mathrm{H}_{25}, \%$ : K, 5.89 (5.77); Co, 1.78 (1.69); W, 66.5 (62.9). TGA shows a weight loss of $6.22 \%$ from $30-400{ }^{\circ} \mathrm{C}$ (calcd. $6.52 \%$ for $12 \mathrm{H}_{2} \mathrm{O}$ ).

$\mathbf{K}_{\mathbf{5}}\left[\mathrm{Co}^{\mathrm{III}} \mathbf{W}_{\mathbf{1 2}} \mathrm{O}_{\mathbf{4 0}}\right] \cdot \mathbf{1 6 H}_{\mathbf{2}} \mathrm{O}\left(\mathrm{Co}^{\mathrm{III}} \mathbf{W}_{\mathbf{1 2}}\right)$. The synthesis was adapted from published methods. ${ }^{41-44}$ Sodium tungstate dihydrate $(19.8 \mathrm{~g}, 60 \mathrm{mmol})$ was dissolved with stirring in $40 \mathrm{~mL}$ of deionized water, after which the $\mathrm{pH}$ was adjusted to 7.0 using glacial acetic acid. A separate solution of cobalt(II) acetate tetrahydrate $(2.5 \mathrm{~g}, 10 \mathrm{mmol})$ in $12 \mathrm{~mL}$ deionized water was prepared, with the $\mathrm{pH}$ adjusted to $c a$. 7 by the addition of a few drops of glacial acetic acid. Both solutions were heated with stirring until near boiling, and the cobalt(II) acetate solution was added to the sodium tungstate solution slowly, yielding a dark green solution. The mixture was boiled for 20 minutes and filtered hot. A $20 \mathrm{~mL}$ saturated solution of potassium acetate adjusted to $\mathrm{pH} 7.0$ by the addition of glacial acetic acid was prepared while the filtrate was reheated. The potassium acetate solution was added slowly to the filtrate with stirring, precipitating a green solid. The resulting mixture was allowed to cool to room temperature and filtered, rinsing the solid twice with the filtrate. The solid was redissolved in $40 \mathrm{~mL} 2 \mathrm{M}$ sulfuric acid with stirring and gentle heating for 15 minutes, yielding a dark blue solution. Insoluble material was removed by filtration. The filtrate was reheated to boiling and potassium persulfate $(1.5 \mathrm{~g}, 5.5 \mathrm{mmol})$ was added in portions until the color change from blue to yellow was complete. The volume of the solution was reduced by half with heating, then allowed to cool to room temperature. Yellow needle crystals developed overnight and were collected by filtration. The product was further purified by passing a concentrated solution through Dowex 50WX8 ion-exchange resin conditioned in the $\mathrm{K}^{+}$cycle. The eluent was evaporated to dryness using a rotary evaporator. The yellow solid was dissolved in minimal deionized water, heated to boiling, and a small amount of potassium persulfate was added to ensure complete oxidation. Yellow needle crystals of $\mathbf{C o}^{\mathrm{III}} \mathbf{W}_{\mathbf{1 2}}$ were obtained via slow evaporation. Yield: $7.41 \mathrm{~g}$ (41.4\% based on W). FTIR (2\% KBr pellet), v, cm cm $^{-1} 954$ (s), 893 (s), 878 (sh), 756 (vs), 500 (w), 442 (m). UVvis $\left(\mathrm{H}_{2} \mathrm{O}\right), \lambda_{\max }, \mathrm{nm}\left(\varepsilon, \mathrm{L} \mathrm{mol}^{-1} \mathrm{~cm}^{-1}\right): 390$ (1270). Elemental analysis: calcd. (found) for $\mathrm{K}_{5} \mathrm{Co}_{1} \mathrm{~W}_{12} \mathrm{O}_{56} \mathrm{H}_{32}$, 
$\%: \mathrm{K}, 5.77$ (5.25); Co, 1.74 (1.75); W, 65.1 (62.0). TGA shows a weight loss of 8.78\% from 30-500 ${ }^{\circ} \mathrm{C}$ (calcd. $8.51 \%$ for $15 \mathrm{H}_{2} \mathrm{O}$ ).

$\mathrm{K}_{\mathbf{9}}\left[\mathrm{Co}^{\mathrm{III}} \mathbf{W}_{11} \mathrm{O}_{39}\right] \cdot \mathbf{1 3 H}_{2} \mathrm{O}\left(\mathrm{Co}^{\mathrm{III}} \mathbf{W}_{\mathbf{1 1}}\right)$. The synthesis was adapted from published methods. ${ }^{45}$ Crystalline $\mathrm{K}_{5}\left[\mathrm{Co}^{\mathrm{III}} \mathrm{W}_{12} \mathrm{O}_{40}\right] \cdot 16 \mathrm{H}_{2} \mathrm{O}(10.0 \mathrm{~g}, 2.9 \mathrm{mmol})$ was dissolved in $25 \mathrm{~mL}$ hot $\left(80{ }^{\circ} \mathrm{C}\right)$ deionized water with stirring. Saturated potassium acetate $\left(10 \mathrm{~mL}, \sim 1 \mathrm{~mL} / 1 \mathrm{~g} \mathrm{Co}{ }^{\mathrm{III}} \mathrm{W}_{12}\right.$ added) was added dropwise to the yellow-orange solution. The solution turned dark quickly upon addition, with a red precipitate forming after $c a .20 \%$ of the potassium acetate solution had been added. Precipitate continued to form throughout the addition process and the solution color changed to turquoise. The red precipitate was filtered hot on a medium glass frit and rinsed with $3 \mathrm{~mL}$ cold deionized water. After air drying overnight, the precipitate was dissolved in minimal boiling deionized water $\left(>90{ }^{\circ} \mathrm{C}, \sim 6.7 \mathrm{~mL} / 1 \mathrm{~g}\right.$ crude product) and filtered hot with coarse filter paper. The dark red filtrate was cooled at $5{ }^{\circ} \mathrm{C}$ overnight to yield small cubic orange-red crystals of $\mathbf{C o}^{\text {III }} \mathbf{W}_{\mathbf{1 1}}$, which were collected on a medium glass frit. Yield: $5.37 \mathrm{~g}$ (55.3\%). FTIR (2\% KBr pellet), v, cm cm $^{-1} 941$ (s), 867 (vs), 839 (sh), 778 (vs), 711 (s), 670 (m), 547 (sh), 517 (w), 495 (w), 470 (sh), $450(\mathrm{~m}), 428(\mathrm{~m})$. UV-vis $\left(\mathrm{H}_{2} \mathrm{O}\right), \lambda_{\max }, \mathrm{nm}\left(\varepsilon, \mathrm{L} \mathrm{mol}^{-1} \mathrm{~cm}^{-1}\right): 390(1340, \mathrm{sh})$. Elemental analysis: calcd. (found) for $\mathrm{K}_{9} \mathrm{Co}_{1} \mathrm{~W}_{11} \mathrm{O}_{57} \mathrm{H}_{36}, \%$ : K, 10.69 (10.00); Co, 1.79 (1.74); W, 61.4 (60.0). TGA shows a weight loss of $7.17 \%$ from $30-425^{\circ} \mathrm{C}$ (calcd. $7.12 \%$ for $13 \mathrm{H}_{2} \mathrm{O}$ ).

$\mathbf{K}_{\mathbf{8}}\left[\mathbf{C o}{ }^{\mathrm{II}}\left(\mathbf{V}^{\mathrm{IV}} \mathbf{O}\right) \mathbf{W}_{\mathbf{1 1}} \mathbf{O}_{\mathbf{3 9}}\right] \cdot \mathbf{1 1 H}_{\mathbf{2}} \mathrm{O}\left(\mathrm{Co}^{\mathrm{II}} \mathbf{V}^{\mathrm{IV}}\right)$. The synthesis was adapted from published methods. ${ }^{45} \mathrm{Vanadyl}$ sulfate pentahydrate $(0.16 \mathrm{~g}, 0.61 \mathrm{mmol})$ was dissolved in $40 \mathrm{~mL}$ potassium acetate buffer, $\mathrm{pH} 5$, and heated to $60{ }^{\circ} \mathrm{C}$. Crystalline $\mathrm{K}_{9}\left[\mathrm{Co}^{\mathrm{III}} \mathrm{W}_{11} \mathrm{O}_{39}\right] \cdot 13 \mathrm{H}_{2} \mathrm{O}(1.0 \mathrm{~g}, 0.30 \mathrm{mmol})$ was added in portions, and the solution turned dark grey-black. The solution was stirred and heated for one hour, filtered, potassium chloride (10 g, $0.13 \mathrm{~mol}$ ) was added, and the solution was cooled at $5{ }^{\circ} \mathrm{C}$ overnight to yield small black crystals. The crude product was collected by filtration, rinsed with $5 \mathrm{~mL}$ cold $2 \mathrm{M}$ potassium chloride solution, and redissolved in minimal hot deionized water. Black cubic crystals of $\mathbf{C o}^{\mathbf{I I}} \mathbf{V}^{\mathbf{I V}}$ were obtained by slow evaporation. Yield: $0.802 \mathrm{~g}(80.4 \%)$. FTIR (2\% KBr pellet), v, $\mathrm{cm}^{-1}: 941$ (s), 879 (sh), 865 (s), 769 (vs), 715 (w), 648 (w), $532(\mathrm{w}), 440(\mathrm{~m})$. UV-vis $\left(\mathrm{H}_{2} \mathrm{O}\right), \lambda_{\max }, \mathrm{nm}\left(\varepsilon, \mathrm{L} \mathrm{mol}^{-1} \mathrm{~cm}^{-1}\right): 445$ (552), 557 (463), 593 (453). Elemental analysis: calcd. (found) for $\mathrm{K}_{8} \mathrm{Co}_{1} \mathrm{~V}_{1} \mathrm{~W}_{11} \mathrm{O}_{51} \mathrm{H}_{22}, \%$ : K, 9.53 (8.83); Co, 1.80 (1.73); V, 1.55 (1.49); W, 61.6 (60.0). TGA shows a weight loss of $6.29 \%$ from $30-375{ }^{\circ} \mathrm{C}$ (calcd. $6.04 \%$ for $11 \mathrm{H}_{2} \mathrm{O}$ ).

$\mathrm{K}_{7}\left[\mathrm{Co}^{\mathrm{II}} \mathrm{Cr}^{\mathrm{III}}\left(\mathrm{H}_{2} \mathrm{O}\right) \mathbf{W}_{11} \mathrm{O}_{39}\right] \cdot \mathbf{1 4 H}_{2} \mathrm{O}\left(\mathrm{Co}^{\mathrm{II}} \mathrm{Cr}^{\mathrm{III}}\right)$. Chromium nitrate nonahydrate (140 $\left.\mathrm{mg}, 0.35 \mathrm{mmol}\right)$ was dissolved in $15 \mathrm{~mL}$ potassium acetate buffer, $\mathrm{pH} 5$, and heated to $60{ }^{\circ} \mathrm{C}$. Crystalline $\mathrm{K}_{9}\left[\mathrm{Co}^{\mathrm{III}} \mathrm{W}_{11} \mathrm{O}_{39}\right] \cdot 13 \mathrm{H}_{2} \mathrm{O}(1.0 \mathrm{~g}, 0.30 \mathrm{mmol})$ was added in portions, and the solution turned dark forest green. The solution was stirred and heated for one hour, during which time sodium ascorbate (60 mg, 0.30 $\mathrm{mmol}$ ) was added. The solution was filtered, potassium chloride $(5.0 \mathrm{~g}, 67 \mathrm{mmol})$ was added, and the solution was cooled at $5{ }^{\circ} \mathrm{C}$ overnight to yield a green solid. The crude product was collected by filtration, rinsed with $5 \mathrm{~mL}$ cold $2 \mathrm{M}$ potassium chloride solution, and redissolved in minimal hot deionized water. Dark green crystals of $\mathbf{C o}^{\mathrm{II}} \mathbf{C r}^{\mathrm{III}}$ were obtained by slow evaporation. Yield: $0.194 \mathrm{~g}$ (19.3\%). FTIR (2\% KBr pellet), v, $\mathrm{cm}^{-1}: 945$ (s), 884 (vs), 764 (vs), 722 (m), 689 (w), 568 (w), 532 (w), 456 (m). UV-vis $\left(\mathrm{H}_{2} \mathrm{O}\right), \lambda_{\max }, \mathrm{nm}\left(\varepsilon, \mathrm{L} \mathrm{mol}^{-1} \mathrm{~cm}^{-1}\right): 624$ (285). Elemental analysis: calcd. (found) for $\mathrm{K}_{7} \mathrm{Co}_{1} \mathrm{Cr}_{1} \mathrm{~W}_{11} \mathrm{O}_{54} \mathrm{H}_{30}$, $\%$ : K, 8.29 (7.87); Co, 1.79 (1.73); Cr, 1.58 (1.61); W, 61.3 (60.6). TGA shows a weight loss of 7.56\% from $30-375{ }^{\circ} \mathrm{C}$ (calcd. $7.64 \%$ for $15 \mathrm{H}_{2} \mathrm{O}$ ).

$\mathbf{K}_{8}\left[\mathbf{C o}^{\mathrm{II}} \mathbf{M n}^{\mathrm{II}}\left(\mathrm{H}_{\mathbf{2}} \mathrm{O}\right) \mathbf{W}_{\mathbf{1 1}} \mathbf{O}_{\mathbf{3 9}}\right] \cdot \mathbf{1 3 H}_{\mathbf{2}} \mathrm{O}\left(\mathrm{Co}^{\mathrm{II}} \mathbf{M n}^{\mathrm{II}}\right)$. Manganese(II) chloride tetrahydrate (69 mg, $\left.0.35 \mathrm{mmol}\right)$ was dissolved in $15 \mathrm{~mL}$ potassium acetate buffer, $\mathrm{pH} \mathrm{5}$, and heated to $60{ }^{\circ} \mathrm{C}$. Crystalline 
$\mathrm{K}_{9}\left[\mathrm{Co}^{\mathrm{III}} \mathrm{W}_{11} \mathrm{O}_{39}\right] \cdot 13 \mathrm{H}_{2} \mathrm{O}(1.0 \mathrm{~g}, 0.30 \mathrm{mmol})$ was added in portions, and the solution turned grey-black. The solution was stirred and heated for one hour, during which time sodium ascorbate $(60 \mathrm{mg}, 0.30$ $\mathrm{mmol})$ was added and the solution turned royal blue. The solution was filtered, potassium chloride $(5.0 \mathrm{~g}$, $67 \mathrm{mmol}$ ) was added, and the solution was cooled at $5{ }^{\circ} \mathrm{C}$ overnight to yield a blue solid. The crude product was collected by filtration, rinsed with $5 \mathrm{~mL}$ cold $2 \mathrm{M}$ potassium chloride solution, and redissolved in minimal hot deionized water. Blue-green crystals of $\mathbf{C o}^{\mathbf{I I}} \mathbf{M n}{ }^{\text {II }}$ were obtained by slow evaporation. Yield: $0.507 \mathrm{~g}$ (50.2\%). FTIR (2\% KBr pellet), v, $\mathrm{cm}^{-1}: 933$ (s), 917 (sh), 859 (vs), 789 (vs), $700(\mathrm{~m}), 528(\mathrm{w}), 475(\mathrm{sh}), 435(\mathrm{~m}) . \mathrm{UV}$-vis $\left(\mathrm{H}_{2} \mathrm{O}\right), \lambda_{\max }, \mathrm{nm}\left(\varepsilon, \mathrm{L} \mathrm{mol}^{-1} \mathrm{~cm}^{-1}\right): 601$ (190). Elemental analysis: calcd. (found) for $\mathrm{K}_{8} \mathrm{Co}_{1} \mathrm{Mn}_{1} \mathrm{~W}_{11} \mathrm{O}_{53} \mathrm{H}_{28}, \%$ : K, 9.41 (8.79); Co, 1.77 (1.86); Mn, 1.65 (1.42); W, 60.8 (60.4). TGA shows a weight loss of $7.03 \%$ from $30-400{ }^{\circ} \mathrm{C}$ (calcd. $7.04 \%$ for $14 \mathrm{H}_{2} \mathrm{O}$ ).

$\mathrm{K}_{7}\left[\mathrm{Co}^{\mathrm{II}} \mathbf{F e}^{\mathrm{III}}\left(\mathrm{H}_{2} \mathrm{O}\right) \mathbf{W}_{11} \mathbf{O}_{39}\right] \bullet \mathbf{1 3 H}_{2} \mathrm{O}\left(\mathrm{Co}^{\mathrm{II}} \mathbf{F e}^{\mathrm{III}}\right)$. Iron(II) sulfate heptahydrate $(97 \mathrm{mg}, 0.35 \mathrm{mmol})$ and crystalline $\mathrm{K}_{9}\left[\mathrm{Co}^{\mathrm{III}} \mathrm{W}_{11} \mathrm{O}_{39}\right] \cdot 13 \mathrm{H}_{2} \mathrm{O}(1.0 \mathrm{~g}, 0.30 \mathrm{mmol})$ were added to $15 \mathrm{~mL}$ potassium acetate buffer, $\mathrm{pH}$ 5 , and stirred at room temperature. The solution gradually turned dark green as the solids dissolved. Once no further color change was observed, the solution was heated at $60{ }^{\circ} \mathrm{C}$ for one hour. The solution was filtered, potassium chloride $(5.0 \mathrm{~g}, 67 \mathrm{mmol})$ was added, and the solution was cooled at $5{ }^{\circ} \mathrm{C}$ overnight to yield a green solid. The crude product was collected by filtration, rinsed with $5 \mathrm{~mL}$ cold $2 \mathrm{M}$ potassium chloride solution, and redissolved in minimal hot deionized water. Dark green crystals of $\mathbf{C o}^{\mathrm{II}} \mathbf{F e}^{\mathrm{III}}$ were obtained by slow evaporation. Yield: $0.780 \mathrm{~g}$ (78.1\%). FTIR (2\% KBr pellet), v, $\mathrm{cm}^{-1}$ : 942 (s), 879 (vs), 763 (vs), 709 (m), 534 (w), 436 (m). UV-vis $\left(\mathrm{H}_{2} \mathrm{O}\right), \lambda_{\max }, \mathrm{nm}\left(\varepsilon, \mathrm{L} \mathrm{mol}^{-1} \mathrm{~cm}^{-1}\right): 477$ (179), 623 (233). Elemental analysis: calcd. (found) for $\mathrm{K}_{7} \mathrm{Co}_{1} \mathrm{Fe}_{1} \mathrm{~W}_{11} \mathrm{O}_{53} \mathrm{H}_{26}, \%$ : K, 8.33 (8.20); Co, 1.79 (1.72); Fe, 1.70 (1.75); W, 61.5 (58.7). TGA shows a weight loss of 7.47\% from $30-350{ }^{\circ} \mathrm{C}$ (calcd. $7.13 \%$ for $14 \mathrm{H}_{2} \mathrm{O}$ ).

$\mathrm{K}_{\mathbf{8}}\left[\mathrm{Co}^{\mathrm{II}} \mathrm{Co}^{\mathrm{II}}\left(\mathrm{H}_{2} \mathrm{O}\right) \mathbf{W}_{\mathbf{1 1}} \mathrm{O}_{39}\right] \bullet \mathbf{1 3 H}_{\mathbf{2}} \mathrm{O}\left(\mathrm{Co}^{\mathrm{II}} \mathrm{Co}^{\mathrm{II}}\right)$. This is an alternative synthetic route, using $\mathrm{Co}^{\mathrm{III}} \mathbf{W}_{\mathbf{1 1}}$, to published methods. ${ }^{42,43}$ Cobalt(II) chloride hexahydrate $(83 \mathrm{mg}, 0.35 \mathrm{mmol})$ was dissolved in $15 \mathrm{~mL}$ potassium acetate buffer, $\mathrm{pH} 5$, and heated to $60{ }^{\circ} \mathrm{C}$. Crystalline $\mathrm{K}_{9}\left[\mathrm{Co}^{\mathrm{III}} \mathrm{W}_{11} \mathrm{O}_{39}\right] \cdot 13 \mathrm{H}_{2} \mathrm{O}(1.0 \mathrm{~g}, 0.30$ mmol) was added in portions, and the solution turned dark red. The solution was stirred and heated for one hour, during which time sodium ascorbate $(60 \mathrm{mg}, 0.30 \mathrm{mmol})$ was added and the solution turned blue. The solution was filtered, potassium chloride $(5.0 \mathrm{~g}, 67 \mathrm{mmol})$ was added, and the solution was cooled at $5{ }^{\circ} \mathrm{C}$ overnight to yield a blue solid. The crude product was collected by filtration, rinsed with 5 $\mathrm{mL}$ cold $2 \mathrm{M}$ potassium chloride solution, and redissolved in minimal hot deionized water. Blue-green crystals of $\mathbf{C o}^{\mathrm{II}} \mathbf{C o}^{\mathrm{II}}$ were obtained by slow evaporation. Yield: $0.433 \mathrm{~g}(42.8 \%)$. FTIR (2\% KBr pellet), $v$, $\mathrm{cm}^{-1}: 933$ (s), 872 (vs), 756 (vs), 658 (w), 532 (w), 473 (sh), $444(\mathrm{~m})$. UV-vis $\left(\mathrm{H}_{2} \mathrm{O}\right), \lambda_{\max }, \mathrm{nm}\left(\varepsilon, \mathrm{L} \mathrm{mol}^{-1}\right.$ $\left.\mathrm{cm}^{-1}\right)$ : 598 (190). Elemental analysis: calcd. (found) for $\mathrm{K}_{8} \mathrm{Co}_{2} \mathrm{~W}_{11} \mathrm{O}_{52} \mathrm{H}_{26}, \%: \mathrm{K}, 9.40$ (8.92); Co, 3.54 (3.79); W, 60.7 (59.7). TGA shows a weight loss of 7.10\% from $30-350{ }^{\circ} \mathrm{C}$ (calcd. $7.03 \%$ for $14 \mathrm{H}_{2} \mathrm{O}$ ).

$\mathbf{K}_{\mathbf{8}}\left[\mathbf{C o}^{\mathrm{II}} \mathbf{N i}^{\mathrm{II}}\left(\mathrm{H}_{2} \mathrm{O}\right) \mathbf{W}_{11} \mathbf{O}_{\mathbf{3 9}}\right] \cdot \mathbf{1 3 H}_{\mathbf{2}} \mathbf{O}\left(\mathbf{C o}^{\mathrm{II}} \mathbf{N i}^{\mathrm{II}}\right)$. Nickel(II) chloride hexahydrate (83 $\left.\mathrm{mg}, 0.35 \mathrm{mmol}\right)$ was dissolved in $25 \mathrm{~mL}$ potassium acetate buffer, $\mathrm{pH} 5$, and heated to $60{ }^{\circ} \mathrm{C}$. Crystalline $\mathrm{K}_{9}\left[\mathrm{Co}^{\mathrm{III}} \mathrm{W}_{11} \mathrm{O}_{39}\right] \cdot 13 \mathrm{H}_{2} \mathrm{O}(1.0 \mathrm{~g}, 0.30 \mathrm{mmol})$ was added in portions, and the solution turned dark brown. The solution was stirred and heated for one hour, during which time sodium ascorbate $(60 \mathrm{mg}, 0.30$ mmol) was added and the solution turned royal blue. The solution was filtered, potassium chloride (10 $\mathrm{g}$, $0.13 \mathrm{~mol}$ ) was added, and the solution was cooled at $5{ }^{\circ} \mathrm{C}$ overnight to yield a blue solid. The crude product was collected by filtration, rinsed with $5 \mathrm{~mL}$ cold $2 \mathrm{M}$ potassium chloride solution, and redissolved in minimal hot deionized water. Blue-green crystals of $\mathbf{C} \mathbf{o}^{\mathrm{II}} \mathbf{N i}^{\mathrm{II}}$ were obtained by slow evaporation. Yield: $0.699 \mathrm{~g}(69.1 \%)$. FTIR (2\% KBr pellet), v, $\mathrm{cm}^{-1}$ : 933 (s), 863 (s), 783 (vs), 708 (w), 
667 (w), $534(\mathrm{w}), 451(\mathrm{~m}), 424(\mathrm{~m})$. UV-vis $\left(\mathrm{H}_{2} \mathrm{O}\right), \lambda_{\max }, \mathrm{nm}\left(\varepsilon, \mathrm{L} \mathrm{mol}^{-1} \mathrm{~cm}^{-1}\right): 624$ (191). Elemental analysis: calcd. (found) for $\mathrm{K}_{8} \mathrm{Co}_{1} \mathrm{Ni}_{1} \mathrm{~W}_{11} \mathrm{O}_{53} \mathrm{H}_{28}$, \%: K, 9.40 (8.98); Co, 1.77 (2.05); Ni, 1.76 (1.64); W, 60.7 (58.6). TGA shows a weight loss of $7.02 \%$ from $30-350{ }^{\circ} \mathrm{C}$ (calcd. $7.04 \%$ for $14 \mathrm{H}_{2} \mathrm{O}$ ).

$\mathrm{K}_{8}\left[\mathrm{Co}^{\mathrm{II}} \mathrm{Cu}^{\mathrm{II}}\left(\mathrm{H}_{2} \mathrm{O}\right) \mathrm{W}_{\mathbf{1 1}} \mathrm{O}_{39}\right] \cdot \mathbf{1 4 H}_{2} \mathrm{O}\left(\mathrm{Co}^{\mathrm{II}} \mathrm{Cu}^{\mathrm{II}}\right)$. The synthesis was adapted from the published method for the synthesis of $\mathrm{K}_{7}\left[\mathrm{Co}^{\mathrm{III}} \mathrm{Cu}^{\mathrm{II}}\left(\mathrm{H}_{2} \mathrm{O}\right) \mathrm{W}_{11} \mathrm{O}_{39}\right]{ }^{46}$ Copper(II) chloride dihydrate $(60 \mathrm{mg}, 0.35 \mathrm{mmol})$ was dissolved in $15 \mathrm{~mL}$ potassium acetate buffer, $\mathrm{pH} 5$, and heated to $60{ }^{\circ} \mathrm{C}$. Crystalline $\mathrm{K}_{9}\left[\mathrm{Co}^{\mathrm{II}} \mathrm{W}_{11} \mathrm{O}_{39}\right] \cdot 13 \mathrm{H}_{2} \mathrm{O}(1.0 \mathrm{~g}, 0.30 \mathrm{mmol})$ was added in portions, and the solution turned dark red. The solution was stirred and heated for one hour, during which time sodium ascorbate $(60 \mathrm{mg}, 0.30 \mathrm{mmol})$ was added and the solution turned dark blue-green. The solution was filtered, potassium chloride $(5.0 \mathrm{~g}$, $67 \mathrm{mmol}$ ) was added, and the solution was cooled at $5{ }^{\circ} \mathrm{C}$ overnight to yield a blue solid. The crude product was collected by filtration, rinsed with $5 \mathrm{~mL}$ cold $2 \mathrm{M}$ potassium chloride solution, and redissolved in minimal hot deionized water. Dark blue-green crystals of $\mathbf{C o}^{\mathrm{II}} \mathbf{C u}^{\mathrm{II}}$ were obtained by slow evaporation. Yield: $0.211 \mathrm{~g}(20.7 \%)$. FTIR (2\% KBr pellet), $v, \mathrm{~cm}^{-1}: 929$ (s), 859 (s), 754 (vs), 696 (w), $660(\mathrm{w}), 444(\mathrm{~m}), 421(\mathrm{~m})$. UV-vis $\left(\mathrm{H}_{2} \mathrm{O}\right), \lambda_{\max }, \mathrm{nm}\left(\varepsilon, \mathrm{L} \mathrm{mol}^{-1} \mathrm{~cm}^{-1}\right): 600$ (199). Elemental analysis: calcd. (found) for $\mathrm{K}_{8} \mathrm{Co}_{1} \mathrm{Cu}_{1} \mathrm{~W}_{11} \mathrm{O}_{54} \mathrm{H}_{30}, \%$ : K, 9.33 (9.00); Co, 1.76 (2.13); $\mathrm{Cu}, 1.90$ (1.64); W, 60.3 (59.3). TGA shows a weight loss of $7.59 \%$ from $30-400{ }^{\circ} \mathrm{C}$ (calcd. $7.52 \%$ for $15 \mathrm{H}_{2} \mathrm{O}$ ).

$\mathrm{K}_{\mathbf{8}}\left[\mathrm{Co}^{\mathrm{II}} \mathbf{Z n}^{\mathrm{II}}\left(\mathrm{H}_{\mathbf{2}} \mathrm{O}\right) \mathbf{W}_{\mathbf{1 1}} \mathbf{O}_{\mathbf{3 9}}\right] \bullet \mathbf{1 4 H}_{\mathbf{2}} \mathrm{O}\left(\mathrm{Co}^{\mathrm{II}} \mathbf{Z n}^{\mathrm{II}}\right)$. Zinc chloride $(48 \mathrm{mg}, 0.35 \mathrm{mmol})$ was dissolved in $15 \mathrm{~mL}$ potassium acetate buffer, $\mathrm{pH} 5$, and heated to $60{ }^{\circ} \mathrm{C}$. Crystalline $\mathrm{K}_{9}\left[\mathrm{Co}^{\mathrm{III}} \mathrm{W}_{11} \mathrm{O}_{39}\right] \cdot 13 \mathrm{H}_{2} \mathrm{O}(1.0 \mathrm{~g}, 0.30$ mmol) was added in portions, and the solution turned orange. The solution was stirred and heated for one hour, during which time sodium ascorbate $(60 \mathrm{mg}, 0.30 \mathrm{mmol})$ was added and the solution turned dark blue. The solution was filtered, potassium chloride $(5.0 \mathrm{~g}, 67 \mathrm{mmol})$ was added, and the solution was cooled at $5{ }^{\circ} \mathrm{C}$ overnight to yield a blue solid. The crude product was collected by filtration, rinsed with 5 $\mathrm{mL}$ cold $2 \mathrm{M}$ potassium chloride solution, and redissolved in minimal hot deionized water. Blue crystals of $\mathrm{Co}^{\mathrm{II}} \mathbf{Z n}^{\mathrm{II}}$ were obtained by slow evaporation. Yield: $0.666 \mathrm{~g}(65.4 \%)$. FTIR (2\% KBr pellet), $v, \mathrm{~cm}^{-}$ 1:934 (s), 921 (sh), 858 (s), 789 (sh), 750 (vs), 704 (m), 535 (w), 442 (m). UV-vis $\left(\mathrm{H}_{2} \mathrm{O}\right), \lambda_{\max }, \mathrm{nm}(\varepsilon, \mathrm{L}$ $\mathrm{mol}^{-1} \mathrm{~cm}^{-1}$ ): 600 (185). Elemental analysis: calcd. (found) for $\mathrm{K}_{8} \mathrm{Co}_{1} \mathrm{Zn}_{1} \mathrm{~W}_{11} \mathrm{O}_{54} \mathrm{H}_{30}, \%: \mathrm{K}, 9.33$ (8.71); Co, 1.76 (1.92); Zn, 1.95 (1.79); W, 60.3 (58.3). TGA shows a weight loss of 7.49\% from $30-500{ }^{\circ} \mathrm{C}$ (calcd. $7.52 \%$ for $\left.15 \mathrm{H}_{2} \mathrm{O}\right)$.

X-ray Crystallography. The dicobalt anion $\mathbf{C o}^{\text {II }} \mathbf{C o}^{\text {II }}$ was synthesized as X-ray diffraction quality crystals of the ammonium salt $\left[\mathrm{NH}_{4}\right]_{7}\left[\mathrm{Co}\left(\mathrm{H}_{2} \mathrm{O}\right)_{6}\right]_{0.5}\left[\mathrm{Co}_{2}\left(\mathrm{H}_{2} \mathrm{O}\right) \mathrm{W}_{11} \mathrm{O}_{39}\right]$ following the method of Baker and McCutcheon. ${ }^{42}$ Suitable single crystals were selected under ambient conditions, mounted on a cryoloop using Paratone-N oil, and placed under the cryostream at $173 \mathrm{~K}$. Crystal evaluation and collection of Xray diffraction intensity data were performed using a Bruker Apex II CCD diffractometer (Mo $\mathrm{K}_{\mathrm{a}}, 1=$ $0.71073 \AA$ ), and data reduction was carried out using the Bruker APEXII program suite. ${ }^{47}$ Correction for incident and diffracted beam absorption effects were applied using numerical methods. ${ }^{48}$ The compound crystallized in $\mathrm{Fm}-3 \mathrm{~m}$ as determined by systematic absences in the intensity data, intensity statistics and the successful solution and refinement of the structure. Structure solution and refinement was carried out using the Bruker SHELXTL software package. ${ }^{49}$ The structure was solved by direct methods and refined against $F^{2}$ by the full matrix least-squares technique. All non-H atoms were refined anisotropically, $\mathrm{H}$ atoms were not located or refined, and the addendum $\mathrm{Co}^{\mathrm{II}}$ atom was 12-fold disordered (position modelled as $16.7 \% \mathrm{Co}, 83.3 \% \mathrm{~W}$ ). Crystal data, data collection parameters and refinement statistics are listed in Table S1, an ORTEP representation of $\mathbf{C o}^{\mathrm{II}} \mathbf{C o} \mathbf{o}^{\mathrm{II}}$ is provided in Figure S1, and bond lengths and angles are tabulated in Table S2, all present in the SI. 
Transient Absorption Measurements. The femtosecond (0.1 ps - $1.2 \mathrm{~ns}$ ) transient absorption (TA) spectrometer used in this study was based on a regeneratively amplified Ti:sapphire laser system (Coherent Legend, $800 \mathrm{~nm}, 150 \mathrm{fs}, 3 \mathrm{~mJ} /$ pulse, $1 \mathrm{kHz}$ repetition rate) and the Helios spectrometer (Ultrafast Systems, LLC). Details about the instrument setup can be found in the previous study. ${ }^{41}$ Samples for transient analysis were filtered with a Whatman $0.2 \mu \mathrm{m}$ PES syringe filter, measured in a 1 $\mathrm{mm}$ path length quartz cuvette to minimize the transient solvent response, constantly stirred by a magnetic stirrer during data collection to minimize localized thermal effects, and the solvent effect in neat buffered solvent was recorded immediately following each sample measurement. No evidence of sample degradation was seen based on comparisons of electronic absorption spectra before and after transient measurements. Detailed analysis of the transient spectra, temporal chirp correction, quantitative kinetic analysis, and global fit analysis via singular value decomposition was performed using Ultrafast Systems Surface Xplorer Pro The principal kinetic components were fit to a multiexponential decay function convoluted with the Gaussian instrument response function (fwhm: $\sim 150 \mathrm{fs}$ ).

Computational Procedure. Geometries of the anions $\left[\mathrm{Co}^{\mathrm{II}}\left(\mathrm{M}^{\mathrm{x}} \mathrm{OH}_{\mathrm{y}}\right) \mathrm{W}_{11} \mathrm{O}_{39}\right]^{(12-\mathrm{x}-\mathrm{y})-},\left[\mathbf{C o M}^{\mathrm{x}}\right]$, and their one-electron oxidized forms $\left[\mathrm{Co}^{\mathrm{II}}\left(\mathrm{M}^{\mathrm{x}} \mathrm{OH}_{\mathrm{y}}\right) \mathrm{W}_{11} \mathrm{O}_{39}\right]^{(11-\mathrm{x}-\mathrm{y})-},\left[\mathbf{C o M}^{\mathrm{x}}\right]^{+}$, for $\mathrm{M}^{\mathrm{x}} \mathrm{OH}_{\mathrm{y}}=\mathrm{V}^{\mathrm{IV}} \mathrm{O}, \mathrm{Cr}^{\mathrm{III}}\left(\mathrm{OH}_{2}\right)$, $\mathrm{Mn}^{\mathrm{II}}\left(\mathrm{OH}_{2}\right), \mathrm{Fe}^{\mathrm{III}}\left(\mathrm{OH}_{2}\right), \mathrm{Co}^{\mathrm{II}}\left(\mathrm{OH}_{2}\right), \mathrm{Ni}^{\mathrm{II}}\left(\mathrm{OH}_{2}\right), \mathrm{Cu}^{\mathrm{II}}\left(\mathrm{OH}_{2}\right)$ and $\mathrm{Zn}^{\mathrm{II}}\left(\mathrm{OH}_{2}\right)$, were optimized at their several lower-lying electronic states in the gas phase with no geometry constraints. Vibrational analyses were performed to ensure that all reported structures are true minima. In these calculations we used the spinunrestricted DFT method (the hybrid B3LYP functional) ${ }^{50-52}$ in conjunction with the D95V $\mathrm{V}^{53,54}$ basis sets for $\mathrm{O}$, and the lanl2dz basis set with the associated Hay-Wadt ECPs ${ }^{55-57}$ for the $\mathrm{W}, \mathrm{V}, \mathrm{Cr}, \mathrm{Mn}, \mathrm{Fe}, \mathrm{Co}, \mathrm{Ni}$, $\mathrm{Cu}$ and $\mathrm{Zn}$ atoms, which below will be referred to as "UB3LYP/lanl2dz". Previously, ${ }^{41,58}$ we have shown that the DFT/lanl2dz approach describes both low-lying electronic states and geometries of the transition metal substituted polyoxometalate anions with reasonable accuracy. Therefore, here we discuss the DFT/lanl2dz calculated geometries and low-lying electronic states of the studied anions with confidence. Solvent effects were applied as single point calculations on top of the gas phase structures and

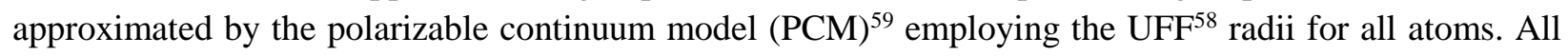
calculations were carried out with the Gaussian 09 software package. ${ }^{60}$

\section{Results and Discussion}

Synthesis. The synthetic strategy used to prepare the reported series of TMSP derivative complexes is an extension of work reported by Bas-Serra et al in isolating $\left[\mathrm{Co}^{\mathrm{III}} \mathrm{W}_{11} \mathrm{O}_{39}\right]^{9-} \cdot{ }^{45}$ Controlled increase of the $\mathrm{pH}$ by addition of potassium acetate to a solution containing the plenary complex $\left[\mathrm{Co}^{\mathrm{III}} \mathrm{W}_{12} \mathrm{O}_{40}\right]^{5-}\left(\mathbf{C o}^{\mathrm{III}} \mathbf{W}_{12}\right)$ leads to the dissociation of a single tungsten oxo $(\mathrm{W}=\mathrm{O})$ unit from the polytungstate framework, converting the plenary complex to the monolacunary complex $\left[\mathrm{Co}^{\mathrm{III}} \mathrm{W}_{11} \mathrm{O}_{39}\right]^{9-}\left(\mathbf{C o}^{\mathrm{III}} \mathbf{W}_{11}\right)$. The resulting lacunary POM serves as a pentadentate ligand, wherein the "pocket" consists of four proximal oxygen atoms $\left(\mathrm{O}^{5}, \mathrm{O}^{6}, \mathrm{O}^{7}\right.$ and $\mathrm{O}^{8}$, in Figure 1) and a fifth oxygen atom $\left(\mathrm{O}^{1}\right)$ bound to the central heteroatom at the center of the complex. Binding of a transition metal (M) within the pocket affords an oxido bound bimetallic complex, where the central tetrahedral heteroatom is indirectly bound to a transition metal with pseudo-octahedral local symmetry. 


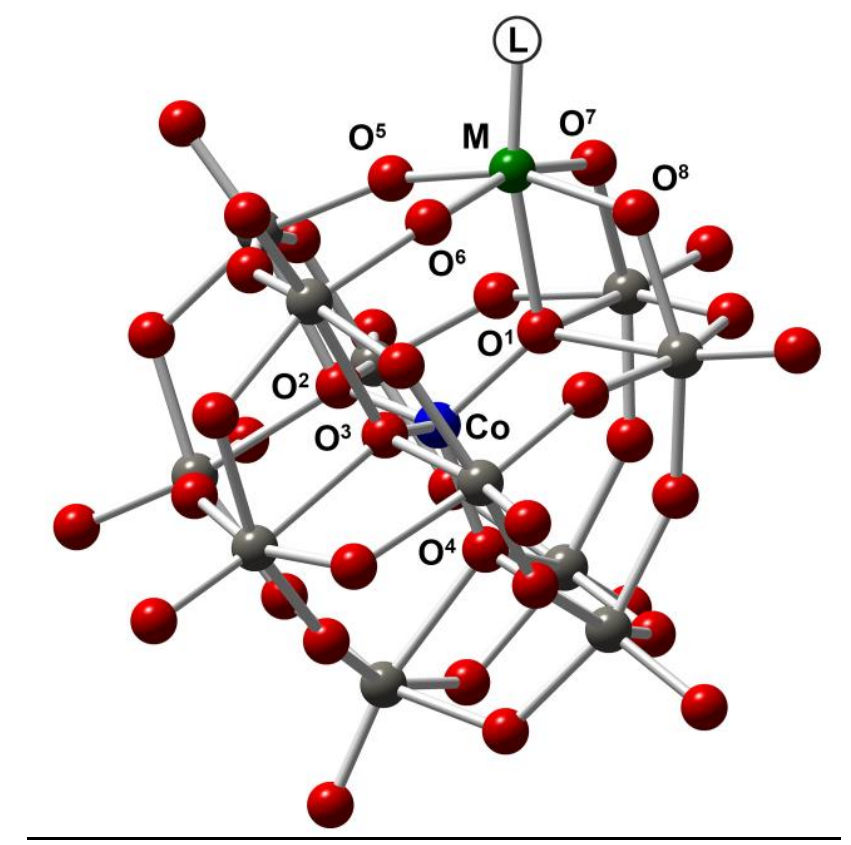

Figure 1. Representative ball-and-stick structure of the TMSP derivatives and notation of the atoms. Color scheme: $\mathrm{W}$, grey; O, red; Co, blue; $\mathrm{M}$, green.

For this study, a range of 3d-transition metals $\left(\mathrm{V}^{4+}\right.$ through $\left.\mathrm{Zn}^{2+}\right)$ were incorporated into $\mathbf{C o}{ }^{\text {III }} \mathbf{W}_{11}$ to evaluate the effect they have on the photodynamics of the plenary complex, $\mathbf{C o}^{\mathrm{II}} \mathbf{W}_{\mathbf{1 2}}$. Binding of the transition metal to $\mathbf{C o}^{\mathrm{II}} \mathbf{W}_{\mathbf{1 1}}$ maintained the trivalent nature of the heteroatom, so to access the desired $\mathrm{Co}^{\mathrm{II}}$-centered anions it was necessary to reduce the resulting $\mathrm{Co}^{\mathrm{III}}$ complexes by one electron. In most cases this was achieved using sodium ascorbate; for $\mathbf{C o}^{\mathbf{I I}} \mathbf{V}^{\mathbf{I V}}$ and $\mathbf{C o}{ }^{\mathbf{I I}} \mathbf{F e} e^{\mathbf{I I I}}$, excess vanadyl sulfate and $\mathrm{Fe}^{2+}$ were used as reducing agents, respectively, to similar effect on cobalt. An analogous series of TMSP complexes, $\left[\mathrm{Co}^{\mathrm{III}}\left(\mathrm{M}^{\mathrm{x}} \mathrm{OH}_{\mathrm{y}}\right) \mathrm{W}_{11} \mathrm{O}_{39}\right]^{(11-\mathrm{x}-\mathrm{y})}$, , is easily synthesized by omitting the reducing agent or using a strong oxidizing agent; this is beyond the scope of the current study. Although single crystals of many of our compounds were obtained, we have limited our structural study to $\mathbf{C o}{ }^{\mathrm{II}} \mathbf{C o}{ }^{\mathrm{II}}$ and comparison with the literature structure of $\left[\mathbf{C o}^{\mathrm{III}} \mathbf{C o}^{\mathrm{II}}\right]^{61}$ and our DFT-calculated bond lengths (vide infra). This is because the high symmetry space groups result in twelve-fold disorder of the addendum heterometal and prevent extraction of accurate bond lengths. Satisfactory characterization of each complex has instead been accomplished by comparison to the lacunary complex $\mathbf{C o}^{\text {III }} \mathbf{W}_{\mathbf{1 1}}$ and its one-electron reduced parent Co ${ }^{\mathrm{II}} \mathbf{W}_{12}$ using infrared and UV-visible spectroscopy, cyclic voltammetry, and elemental analysis.

Calculated Ground State Geometries and Electronic Structures. Calculated important bond lengths and un-paired spin densities of selected atoms of the experimentally prepared TMSP anions $\left[\mathbf{C o M}^{\mathbf{x}}\right]$, as well as their one-electron oxidized forms $\left[\mathbf{C o M}^{\mathrm{x}}\right]^{+}$, for $\mathrm{M}^{\mathrm{x}}=\mathrm{V}^{\mathrm{IV}}, \mathrm{Cr}^{\mathrm{III}}, \mathrm{Mn}^{\mathrm{II}}, \mathrm{Fe}^{\mathrm{III}}, \mathrm{Co}^{\mathrm{II}}, \mathrm{Ni}^{\mathrm{II}}, \mathrm{Cu}^{\mathrm{II}}, \mathrm{Zn}^{\mathrm{II}}$, are summarized in Table 1. A representative structure of the calculated systems with notation of atoms is given in Figure 1. Full calculated geometries (Cartesian coordinates) for all reported TMSP anions in this paper, in their lower-lying electronic states, are provided in the SI (Table S4). 
Table 1. The calculated important bond distances (in $\AA$ ), unpaired spin densities (in |e|), and one-electron oxidation potential (in kcal/mol) for TMSP anions $\left[\mathrm{Co}^{\mathrm{II}}\left(\mathrm{M}^{\mathrm{x}} \mathrm{OH}_{\mathrm{y}}\right) \mathrm{W}_{11} \mathrm{O}_{39}\right]^{(12-\mathrm{x}-\mathrm{y})-},\left[\mathbf{C o M}^{\mathrm{x}}\right]$, and their one-electron oxidized forms $\left[\mathbf{C o M}^{\mathrm{x}}\right]^{+}$

\begin{tabular}{|c|c|c|c|c|c|c|c|c|c|c|c|c|c|c|c|c|}
\hline \multirow[t]{2}{*}{ Par. } & \multicolumn{2}{|c|}{$\mathrm{M}=\mathrm{V}^{\mathrm{IV}}$} & \multicolumn{2}{|c|}{$\mathrm{M}=\mathrm{Cr}^{\mathrm{III}}$} & \multicolumn{2}{|c|}{$\mathrm{M}=\mathrm{Mn}^{\mathrm{II}}$} & \multicolumn{2}{|c|}{$\mathrm{M}=\mathrm{Fe}^{\mathrm{III}}$} & \multicolumn{2}{|c|}{$\mathrm{M}=\mathrm{Co}^{\mathrm{II}}$} & \multicolumn{2}{|c|}{$\mathrm{M}=\mathrm{Ni}^{\mathrm{II}}$} & \multicolumn{2}{|c|}{$\mathrm{M}=\mathrm{Cu}^{\mathrm{II}}$} & \multicolumn{2}{|c|}{$\mathrm{M}=\mathrm{Zn}^{\mathrm{II}}$} \\
\hline & {$\left[\mathrm{Co}^{\mathrm{I}} \mathrm{V}^{\mathrm{I}}\right]$} & {$\left[\mathrm{Co}^{\mathrm{u}} \mathrm{V}^{\mathrm{v}}\right]$} & {$\left[\mathrm{Co}^{\mathrm{I}} \mathrm{Cr}{ }^{\mathrm{II}}\right]$} & {$\left[\mathrm{Co}^{\mathrm{III}} \mathrm{Cr}^{\mathrm{II}}\right]$} & {$\left[\mathrm{Co}^{"} \mathrm{Mn}^{\mathrm{n}}\right]$} & {$\left[\mathrm{Co}^{\mathrm{I}} \mathrm{Mn}{ }^{\mathrm{II}}\right]$} & [Co"li" Fe"] & {$\left[\mathrm{CO}^{\left.\mathrm{II}^{\mathrm{Fe}} \mathrm{e}^{\mathrm{II}}\right]}\right.$} & {$\left[\mathrm{Co}^{\prime \prime} \mathrm{Co}^{\prime \prime}\right]$} & {$\left[\mathrm{Co}^{\mathrm{III}} \mathrm{Co} \mathrm{o}^{\mathrm{I}}\right]$} & {$\left[\mathrm{Co}^{\left.\mathrm{uN}^{\mathrm{N}} \mathrm{H}\right]}\right.$} & {$\left[\mathrm{Co}^{\mathrm{II}} \mathrm{Ni}^{\mathrm{H}}\right]$} & {$\left[\mathrm{Co}^{\prime \prime} \mathrm{Cu}^{\prime \prime}\right]$} & {$\left[\mathrm{Co}^{\mathrm{III}} \mathrm{Cu}^{\mathrm{I}}\right]$} & {$\left[\mathrm{CO}^{\mathrm{IZZ}} \mathrm{Zn}^{\mathrm{N}}\right.$} & 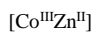 \\
\hline \multicolumn{17}{|c|}{ Important Bond Distances (in Å) } \\
\hline $\mathrm{M}-\mathrm{O}^{1}$ & 2.25 & 2.28 & 1.87 & 1.89 & 2.16 & 2.07 & 2.09 & 2.01 & 2.03 & 2.08 & 1.99 & 2.02 & 2.19 & 2.23 & 2.02 & 2.07 \\
\hline $\mathrm{M}-\mathrm{O}^{5}$ & 1.99 & 1.98 & 1.96 & 1.94 & 1.94 & 1.93 & 2.06 & 1.96 & 2.06 & 2.04 & 2.05 & 2.04 & 2.02 & 2.00 & 2.05 & 2.05 \\
\hline $\mathrm{M}-\mathrm{O}^{6}$ & 1.99 & 1.98 & 1.96 & 1.95 & 1.93 & 1.91 & 2.01 & 1.96 & 2.02 & 2.01 & 2.02 & 2.00 & 1.98 & 1.98 & 2.05 & 2.05 \\
\hline $\mathrm{M}-\mathrm{O}^{7}$ & 2.03 & 1.84 & 2.00 & 1.98 & 1.92 & 1.96 & 2.17 & 2.04 & 2.18 & 2.13 & 2.13 & 2.11 & 2.06 & 2.05 & 2.21 & 2.15 \\
\hline $\mathrm{M}-\mathrm{O}^{8}$ & 2.03 & 1.84 & 2.00 & 1.99 & 1.93 & 1.96 & 2.19 & 2.03 & 2.18 & 2.13 & 2.12 & 2.09 & 2.10 & 2.04 & 2.21 & 2.15 \\
\hline $\mathrm{Co}-\mathrm{O}^{1}$ & 1.91 & 1.90 & 1.94 & 1.87 & 1.91 & 1.92 & 1.85 & 1.86 & 1.94 & 1.85 & 1.93 & 1.85 & 1.92 & 1.81 & 1.94 & 1.84 \\
\hline $\mathrm{Co}-\mathrm{O}^{2}$ & 1.93 & 1.92 & 1.91 & 1.83 & 1.93 & 1.92 & 1.85 & 1.83 & 1.94 & 1.85 & 1.93 & 1.84 & 1.93 & 1.85 & 1.94 & 1.85 \\
\hline $\mathrm{Co}-\mathrm{O}^{3}$ & 1.93 & 1.92 & 1.91 & 1.81 & 1.93 & 1.92 & 1.85 & 1.82 & 1.94 & 1.85 & 1.93 & 1.85 & 1.93 & 1.85 & 1.94 & 1.85 \\
\hline $\mathrm{Co}-\mathrm{O}^{4}$ & 1.92 & 1.92 & 1.90 & 1.82 & 1.92 & 1.91 & 1.85 & 1.84 & 1.94 & 1.85 & 1.93 & 1.84 & 1.93 & 1.86 & 1.92 & 1.84 \\
\hline \multicolumn{17}{|c|}{ Unpaired Spin Densities (in |e|) } \\
\hline M & 1.10 & 0.00 & 3.01 & 2.99 & 2.88 & 3.80 & 3.78 & 4.12 & 2.71 & 2.72 & 1.65 & 1.67 & 0.65 & 0.65 & 0.00 & 0.00 \\
\hline Co & 2.73 & 2.73 & 2.72 & 2.98 & 2.22 & 2.73 & 2.99 & 3.01 & 2.73 & 3.00 & 2.74 & 3.00 & 2.73 & 2.98 & 2.73 & 2.99 \\
\hline $\mathrm{O}^{1}$ & 0.06 & 0.06 & 0.01 & 0.13 & 0.17 & 0.19 & 0.30 & 0.42 & 0.15 & 0.30 & 0.19 & 0.33 & 0.06 & 0.32 & 0.06 & 0.25 \\
\hline $\mathrm{O}^{2}$ & 0.06 & 0.06 & 0.06 & 0.25 & 0.06 & 0.06 & 0.23 & 0.25 & 0.06 & 0.24 & 0.06 & 0.24 & 0.06 & 0.22 & 0.06 & 0.23 \\
\hline $\mathrm{O}^{3}$ & 0.06 & 0.06 & 0.06 & 0.28 & 0.06 & 0.06 & 0.23 & 0.26 & 0.06 & 0.24 & 0.06 & 0.24 & 0.06 & 0.21 & 0.06 & 0.23 \\
\hline $\mathrm{O}^{4}$ & 0.06 & 0.06 & 0.06 & 0.25 & 0.06 & 0.06 & 0.22 & 0.24 & 0.06 & 0.24 & 0.06 & 0.24 & 0.06 & 0.21 & 0.06 & 0.23 \\
\hline $\mathrm{O}^{5}$ & -0.01 & 0.00 & 0.00 & 0.00 & 0.01 & 0.01 & 0.04 & 0.15 & 0.04 & 0.04 & 0.04 & 0.04 & 0.07 & 0.07 & 0.00 & 0.00 \\
\hline $\mathrm{O}^{6}$ & -0.01 & 0.00 & 0.00 & 0.00 & 0.01 & 0.01 & 0.04 & 0.16 & 0.04 & 0.04 & 0.04 & 0.05 & 0.07 & 0.07 & 0.00 & 0.00 \\
\hline $\mathrm{O}^{7}$ & 0.00 & 0.00 & -0.01 & 0.00 & 0.00 & 0.00 & 0.04 & 0.15 & 0.04 & 0.04 & 0.06 & 0.06 & 0.10 & 0.10 & 0.00 & 0.00 \\
\hline $\mathrm{O}^{8}$ & 0.00 & 0.00 & -0.01 & 0.00 & 0.00 & 0.00 & 0.04 & 0.16 & 0.04 & 0.04 & 0.06 & 0.06 & 0.07 & 0.10 & 0.00 & 0.00 \\
\hline $\mathrm{CoO}_{4}$ & 2.97 & 2.97 & 2.91 & 3.89 & 2.57 & 3.10 & 3.97 & 4.17 & 3.06 & 4.02 & 3.11 & 4.05 & 2.97 & 3.94 & 2.97 & 3.93 \\
\hline $\mathrm{MO}_{4}$ & 1.08 & 0.00 & 2.99 & 2.99 & 2.90 & 3.82 & 3.94 & 4.74 & 2.87 & 2.88 & 1.85 & 1.88 & 0.96 & 0.99 & 0.00 & 0.00 \\
\hline \multicolumn{17}{|c|}{ One-Electron Oxidation Potential (kcal/mol) } \\
\hline$\Delta \mathrm{E}_{\mathrm{ox}}$ & 98.7 & - & 113.0 & - & 69.0 & - & 100.1 & - & 101.5 & - & 105.0 & - & 98.0 & - & 98.6 & - \\
\hline
\end{tabular}


Previously we (and others) have shown, ${ }^{41,62-64}$ through experimental and computational investigation, that the Co-O bond lengths around the central cobalt in $\mathbf{C o}^{\mathbf{I I}} \mathbf{W}_{\mathbf{1 2}}$ (i.e. Co-O $\mathrm{O}^{1,2,3,4}$ bond distances in Table 1, see also Figure 1) and total spin densities of the $\mathrm{CoO}_{4}$-unit are indicative of the cobalt oxidation state. The Co-O bond lengths around the central cobalt are significantly longer for the $\left[\mathrm{Co}^{\mathrm{II}} \mathrm{O}_{4}\right]$ fragment than for $\left[\mathrm{Co}^{\mathrm{III}} \mathrm{O}_{4}\right]$. Similarly, here, we use both the DFT-calculated Co-O bond lengths around the central cobalt and amount of the unpaired spin densities in the $\mathrm{MO}_{4}$ - and $\mathrm{CoO}_{4}$-units to determine the oxidation states of the $\mathrm{M}$ and Co-centers in anions $\left[\mathrm{CoM}^{\mathrm{x}}\right]$ and $\left[\mathrm{CoM}^{\mathrm{x}}\right]^{+}$. X-ray crystal structures of $\mathbf{C o}^{\mathrm{II}} \mathbf{C o}^{\mathrm{II}}$ (see SI) and $\mathrm{Co}^{\text {III }} \mathbf{C o}^{\text {II }}{ }^{61}$ indicate that our calculations replicate the geometric structures of these anions well. The central, tetrahedral Co in $\mathbf{C o}^{\mathrm{II}} \mathbf{C o}^{\mathrm{II}}$ has a Co-O bond length of 1.914(7) $\AA$ (effectively an average of both Co-O-W and Co-O-Co due to disorder), while in $\mathbf{C o}^{\text {III }} \mathbf{C o}^{\text {II }}$ this contracts to $1.82(2) \AA$. In our calculations, these distances are 1.94 and $1.85 \AA$ respectively, and the small difference of ca. $0.03 \AA$ is unsurprising when comparing solid state structures to those of calculated molecular systems.

Calculations show that the anion $\left[\mathrm{Co}(\mathrm{VO}) \mathrm{W}_{11} \mathrm{O}_{39}\right]^{8-}$ has energetically degenerate ferromagnetic ${ }^{5} \mathrm{~A}$ and anti-ferromagnetic ${ }^{3} \mathrm{~A}$ electronic states with $\mathrm{Co}\left(\mathrm{d}^{7}\right)$ and $\mathrm{V}\left(\mathrm{d}^{1}\right)$-centers. In its ${ }^{3} \mathrm{~A}$ electronic state the Cocenter possesses three $\alpha$-spins, while the $\mathrm{V}$-center holds only one $\beta$-spin. Thus, this anion should be characterized as a $\left[\mathrm{Co}^{\mathrm{II}}\left(\mathrm{V}^{\mathrm{IV}} \mathrm{O}\right) \mathrm{W}_{11} \mathrm{O}_{39}\right]^{8-}\left(\mathbf{C o}^{\mathrm{II}} \mathbf{V}^{\mathrm{IV}}\right)$ species. As seen in Table 1 , the $(\mathrm{VO})$ unit in this anion only weakly interacts with both the internal $\mathrm{CoO}_{4}$ fragment (the calculated $\mathrm{V}-\mathrm{O}^{1}$ distance is $2.25 \AA$ ) and W-framework (calculated $\mathrm{V}-\mathrm{O}^{5,6,7,8}$ distances are 2.03-1.99 $\AA$ ). One electron oxidation of $\mathbf{C o}^{\mathrm{II}} \mathbf{V}^{\mathrm{IV}}$ is associated with the removal of an unpaired electron from the $\mathrm{V}$-center and leads to the formation of the $\left[\mathrm{Co}^{\mathrm{II}}\left(\mathrm{V}^{\mathrm{V}} \mathrm{O}\right) \mathrm{W}_{11} \mathrm{O}_{39}\right]^{7-}$ anion $\left(\mathbf{C o}^{\mathrm{II}} \mathbf{V}^{\mathbf{V}}\right.$ in Table 1$)$ with a $\mathrm{d}^{0}$ vanadium center. The ground electronic state of this $\mathbf{C o} \mathbf{o}^{\text {II }} \mathbf{V}^{\mathbf{V}}$ anion is a high-spin $S=3 / 2$ quartet state. Interestingly, the oxidation from $\mathbf{C o}^{\mathbf{I I}} \mathbf{V}^{\mathbf{I V}}$ to $\mathbf{C o}^{\mathrm{II}} \mathbf{V}^{\mathbf{V}}$ results in a shortening of the $\mathrm{V}-\mathrm{O}^{5,6}(\mathrm{~W})$ bonds. Therefore, $\mathbf{C o}^{\mathbf{I I}} \mathbf{V}^{\mathbf{V}}$ is expected to be more stable (against dissociation of the vanadyl fragment) than its parent $\mathbf{C o}^{\mathbf{I I}} \mathbf{V}^{\mathbf{I V}}$.

Anion $\left[\mathrm{CoCr}\left(\mathrm{H}_{2} \mathrm{O}\right) \mathrm{W}_{11} \mathrm{O}_{39}\right]^{7-}$ is also found to have energetically degenerate ferromagnetic and antiferromagnetic coupled ${ }^{7} \mathrm{~A}$ and ${ }^{1} \mathrm{~A}$-states with $\mathrm{S}=3$ total spin and $\operatorname{Co}\left(\mathrm{d}^{7}\right)$ and $\operatorname{Cr}\left(\mathrm{d}^{3}\right)$-centers. Thus, it should be characterized as a $\left[\mathrm{Co}^{\mathrm{II}} \mathrm{Cr}^{\mathrm{III}}\left(\mathrm{H}_{2} \mathrm{O}\right) \mathrm{W}_{11} \mathrm{O}_{39}\right]^{7-}\left(\mathbf{C o}^{\mathrm{II}} \mathbf{C r}^{\mathrm{III}}\right)$ species. The calculated $\mathrm{Cr}-\mathrm{O}^{1}(\mathrm{Co})$ bond in $\mathrm{Co}^{\mathrm{II}} \mathbf{C r}^{\mathrm{III}}$ is significantly shorter than the $\mathrm{V}^{-} \mathrm{O}^{1}(\mathrm{Co})$ bond in $\mathbf{C o}^{\mathrm{II}} \mathbf{V}^{\mathrm{IV}}$. Calculated spin densities as well as $\mathrm{Co}-\mathrm{O}$ bond distances in the $\mathrm{CoO}_{4}$-core clearly show that one electron oxidation of $\mathbf{C o}^{\text {II }} \mathbf{C r}^{\text {III }}$ corresponds to removal of an electron from the Co-center, rather than from the $\mathrm{Cr}$-center. Therefore, the one-electron oxidized form of $\mathbf{C o}^{\mathrm{II}} \mathbf{C r}^{\mathrm{III}}$ should be characterized as a $\left[\mathrm{Co}^{\mathrm{III}} \mathrm{Cr}^{\mathrm{III}}\left(\mathrm{H}_{2} \mathrm{O}\right) \mathrm{W}_{11} \mathrm{O}_{39}\right]^{6-}$ anion $\left(\mathbf{C o}^{\mathrm{III}} \mathbf{C r}^{\mathrm{III}}\right)$. Indeed, in the $\mathbf{C o}^{\mathrm{III}} \mathbf{C r}^{\mathrm{III}}$ anion the calculated $\mathrm{Co}-\mathrm{O}$ bond distances are significantly shorter than those in the parent compound $\mathbf{C o}^{\mathrm{II}} \mathbf{C r}^{\mathrm{III}}$. Furthermore, the calculated spin density on the $\mathrm{CoO}_{4}$-unit of $\mathrm{Co}^{\mathrm{III}} \mathrm{Cr}^{\mathrm{III}}$ is close to four, consistent with a tetrahedral $\mathrm{Co}\left(\mathrm{d}^{6}\right)$-center. It should be emphasized that oxidation of $\mathrm{Co}^{\mathrm{II}} \mathbf{C r}^{\mathrm{III}}$ to $\mathrm{Co}^{\mathrm{III}} \mathbf{C r}^{\mathrm{III}}$ leads to slight elongation of the $\mathrm{Cr}^{-} \mathrm{O}^{1}(\mathrm{Co})$ bond, likely because of strengthening of the competing $\mathrm{Co}-\mathrm{O}^{1}(\mathrm{Cr})$ bond.

The Mn-atom of anion $\left[\mathrm{CoMn}\left(\mathrm{H}_{2} \mathrm{O}\right) \mathrm{W}_{11} \mathrm{O}_{39}\right]^{8-}$ in its energetically lowest and degenerate ferromagnetically and anti-ferromagnetically coupled ${ }^{7} \mathrm{~A}$ and ${ }^{1} \mathrm{~A}$-states with $\mathrm{S}=3$ total spin, and with $\operatorname{Co}\left(\mathrm{d}^{7}\right)$ and $\mathrm{Mn}\left(\mathrm{d}^{5}\right)$-centers, is found to have only three unpaired spins. Its ${ }^{9} \mathrm{~A}$ electronic state with $\mathrm{S}=4$ total spin and $\operatorname{Mn}\left(\mathrm{d}^{5}\right)$-center with five unpaired $\alpha$-spins lies only $c a .1 \mathrm{kcal} / \mathrm{mol}$ higher. Thus, anion $\left[\mathrm{CoMn}\left(\mathrm{H}_{2} \mathrm{O}\right) \mathrm{W}_{11} \mathrm{O}_{39}\right]^{8-}$ could be characterized as a $\left[\mathrm{Co}^{\mathrm{II}} \mathrm{Mn}^{\mathrm{II}}\left(\mathrm{H}_{2} \mathrm{O}\right) \mathrm{W}_{11} \mathrm{O}_{39}\right]^{8-}\left(\mathbf{C o}^{\mathrm{II}} \mathbf{M n}^{\mathrm{II}}\right)$. One electron oxidation of $\mathbf{C o}^{\text {II }} \mathbf{M n}^{\text {II }}$, in contrast to $\mathrm{Co}^{\text {II }} \mathbf{C r}^{\text {III }}$, leads to oxidation of the Mn-center, rather than the Cocenter. As seen in Table 1, in $\left[\mathrm{CoMn}\left(\mathrm{H}_{2} \mathrm{O}\right) \mathrm{W}_{11} \mathrm{O}_{39}\right]^{7-}$, the Mn-center possesses almost four unpaired spins in its energetically lowest ${ }^{8} \mathrm{~A}$ and ${ }^{2} \mathrm{~A}$-states with $\mathrm{S}=7 / 2$ total spin. Thus, one electron oxidation of 
$\mathbf{C o}^{\mathrm{II}} \mathbf{M n}^{\mathrm{II}}$ leads to the $\left[\mathrm{Co}^{\mathrm{II}} \mathrm{Mn}^{\mathrm{III}}\left(\mathrm{H}_{2} \mathrm{O}\right) \mathrm{W}_{11} \mathrm{O}_{39}\right]^{7-}\left(\mathbf{C o}^{\mathrm{II}} \mathbf{M n}^{\mathrm{III}}\right)$ anion. Once again, one-electron oxidation of $\mathrm{Co}^{\mathrm{II}} \mathrm{Mn}^{\mathrm{II}}$ elongates the $\mathrm{M}-\mathrm{O}^{1}(\mathrm{Co})$ bond distance.

Calculations show that for the second half of the transition metal series $\left(\mathrm{M}=\mathrm{Fe}^{\mathrm{III}}\right.$ to $\left.\mathrm{Zn}^{\mathrm{II}}\right)$ all the anions are the $\left[\mathrm{Co}^{\mathrm{II}} \mathbf{M}^{\mathrm{x}}\left(\mathrm{H}_{2} \mathrm{O}\right) \mathrm{W}_{11} \mathrm{O}_{39}\right]^{(10-\mathrm{x})-}\left(\mathbf{C o}^{\mathrm{II}} \mathbf{M}^{\mathrm{II}}\right.$ or $\left.\mathbf{C o}{ }^{\mathrm{II}} \mathbf{M}^{\mathrm{III}}\right)$, species, and their one-electron oxidation associates with the removal of an electron from the $\mathrm{CoO}_{4}$-fragment. ${ }^{65}$ As seen in Table 1, upon oxidation from $\left[\mathrm{Co}^{\mathrm{II}} \mathbf{M}^{\mathrm{I}}\right]$ to $\left[\mathrm{Co}^{\mathrm{II}} \mathbf{M}^{\mathrm{II}}\right]^{+}$(where $\mathrm{M}=\mathrm{Fe}, \mathrm{Co}, \mathrm{Ni}, \mathrm{Cu}$ and $\mathrm{Zn}$ ) the number of unpaired spins in $\mathrm{M}$ centers does not change, but it increases by one in the $\mathrm{CoO}_{4}$-fragment. In addition, the $\mathrm{Co}-\mathrm{O}$ bond distances in the $\mathrm{CoO}_{4}$-unit significantly shorten upon this one-electron oxidation process.

In order to support the findings above we also calculated a one-electron oxidation potential for all reported anions, i.e. reactions $\mathrm{Co}^{\mathrm{II}} \mathbf{V}^{\mathrm{IV}} \rightarrow \mathrm{Co}^{\mathrm{II}} \mathbf{V}^{\mathrm{V}}, \mathrm{Co}^{\mathrm{II}} \mathrm{Cr}^{\mathrm{III}} \rightarrow \mathrm{Co}^{\mathrm{III}} \mathrm{Cr}^{\mathrm{III}}, \mathrm{Co}^{\mathrm{II}} \mathbf{M n}^{\mathrm{II}} \rightarrow \mathrm{Co}^{\mathrm{II}} \mathrm{Mn}^{\mathrm{III}}$, $\mathrm{Co}^{\mathrm{II}} \mathrm{Fe}^{\mathrm{III}} \rightarrow \mathrm{Co}^{\mathrm{III}} \mathbf{F e}^{\mathrm{III}}$, and $\mathrm{Co}^{\mathrm{II}} \mathbf{M}^{\mathrm{II}} \rightarrow \mathrm{Co}^{\mathrm{III}} \mathbf{M}^{\mathrm{II}}$, where $\mathrm{M}=\mathrm{Co}, \mathrm{Ni}, \mathrm{Cu}$ and $\mathrm{Zn}$. In these calculations, we assumed that the electron dissociates directly to the water solution, while we did not include hydration energy of the electron into our final results. Therefore, absolute values of these calculated energies should be used with caution, while the relative changes of these values could be useful in determining the nature of the oxidation process. As seen in Table 1, the energy of these reactions is close for $\mathrm{M}=\mathrm{Cr}, \mathrm{Fe}, \mathrm{Co}, \mathrm{Ni}$, $\mathrm{Cu}$, and $\mathrm{Zn}$, which suggests that the central $\mathrm{Co}^{\mathrm{II}}$ heteroatom is oxidized in these systems. Deviation of the calculated values from that for the system with $\mathrm{M}=\mathrm{Co}$ could be used to estimate the degree of electronic coupling between the Co- and M-centers, which varies as $\mathrm{M}=\mathrm{Cr} \gg \mathrm{Ni} \cong \mathrm{Cu}>\mathrm{Zn}>\mathrm{V}>\mathrm{Fe}$. The calculated value for the system with $\mathrm{M}=\mathrm{Mn}$ is very different from that for the other anions, indicative of oxidation occurring at the addendum heterometal.

In summary, the computational data clearly show that the removal of an electron from $\left[\mathrm{Co}^{\mathrm{II}}\left(\mathrm{V}^{\mathrm{IV}} \mathrm{O}\right) \mathrm{W}_{11} \mathrm{O}_{39}\right]^{8-}$ and $\left[\mathrm{Co}^{\mathrm{II}} \mathrm{Mn}^{\mathrm{II}}\left(\mathrm{H}_{2} \mathrm{O}\right) \mathrm{W}_{11} \mathrm{O}_{39}\right]^{8-}$ oxidizes vanadium and manganese centers, respectively. In contrast, the removal of an electron from $\left[\mathrm{Co}^{\mathrm{II}} \mathrm{M}^{\mathrm{x}}\left(\mathrm{H}_{2} \mathrm{O}\right) \mathrm{W}_{11} \mathrm{O}_{39}\right]^{(10-\mathrm{x})-}$ anions for $\mathrm{M}=\mathrm{Cr}^{\mathrm{III}}$, $\mathrm{Fe}^{\mathrm{III}}, \mathrm{Co}^{\mathrm{II}}, \mathrm{Ni}^{\mathrm{II}}, \mathrm{Cu}^{\mathrm{II}}$ and $\mathrm{Zn}^{\mathrm{II}}$ oxidizes the Co-center of the $\mathrm{CoO}_{4}$-unit, and leads to elongation of the M$\mathrm{O}(\mathrm{Co})$ bond distance. Furthermore, all calculated TMSP anions are found to have energetically degenerate ferromagnetically and anti-ferromagnetically coupled ground electronic states with unpaired electrons on $\mathrm{M}$ - and Co-centers.

Static Infrared Spectroscopy. Successful incorporation of a transition metal within the pocket of a lacunary POM was verified by infrared spectroscopy. The IR spectrum for each TMSP complex and the precursor POM complexes $\mathbf{C o}^{\mathrm{II}} \mathbf{W}_{12}, \mathbf{C o}^{\mathrm{III}} \mathbf{W}_{12}$, and $\mathbf{C o}^{\mathrm{III}} \mathbf{W}_{11}$ are superimposed in Figure S2. The plenary complexes exhibit relatively few IR absorption bands due to their high symmetry. The reduction in symmetry upon formation of $\mathbf{C o}^{\text {III }} \mathbf{W}_{\mathbf{1 1}}$ leads to the observation of splitting of the W-O-W bands around $850 \mathrm{~cm}^{-1}$ and $750 \mathrm{~cm}^{-1}$. This splitting is a general feature of lacunary POMs. ${ }^{66,67}$ The incorporation of a transition metal into the lacunary POM leads to an increase in the symmetry of the complex, causing the characteristic W-O-W splitting to disappear for all TMSP complexes.

Static Electronic Absorption Spectroscopy. Comparison of the UV-visible absorption bands for each TMSP complex to the plenary complexes $\mathbf{C o}^{\mathbf{I I}} \mathbf{W}_{\mathbf{1 2}}$ and $\mathbf{C o} \mathbf{C}^{\mathrm{III}} \mathbf{W}_{\mathbf{1 2}}$, supported by the results of our calculations, allows for definitive assignment of the electronic transitions in this series. Comparison of the 
absorption bands to the plenary complex will also permit an investigation into the changes in electronic structure caused by substitution of a transition metal into the polytungstate framework.

The UV-visible absorption spectra for all complexes contain strong UV absorptions at 180 and $250 \mathrm{~nm}$ arising from $\mathrm{O}_{2 \mathrm{p}} \rightarrow \mathrm{W}_{5 \mathrm{~d}}$ charge transfer transitions, a common feature in all polyoxotungstates. As previously reported, ${ }^{41}$ the presence of a cobalt heteroatom introduces lower energy features consistent with MPCT and metal-centered electronic transitions. The UV-visible absorption spectra for this series (Figure 2) are consistent with previous assignments. Each complex exhibits a definitive feature centered at $\sim 625 \mathrm{~nm}$ associated with the ${ }^{4} \mathrm{~A}_{2} \rightarrow{ }^{4} \mathrm{~T}_{1} \mathrm{~d}$-d transition of the tetrahedral $\mathrm{Co}^{\mathrm{II}}$ heteroatom. The extinction coefficient at $625 \mathrm{~nm}$ is similar to that of the plenary complex, varying by less than $20 \%$ in all but two cases (Table 2). The most extreme deviation occurs for $\mathbf{C o}^{\mathbf{I I}} \mathbf{V}^{\mathrm{IV}}$, where the lower lying orbitals of $\mathrm{V}^{\mathrm{IV}}$ result in the significant presence of $\mathrm{O}_{2 \mathrm{p}} \rightarrow \mathrm{V}_{3 \mathrm{~d}}$ transitions tailing well into the visible spectrum, causing a marked increase in the extinction coefficients for this complex and the appearance that the cobalt ${ }^{4} \mathrm{~A}_{2} \rightarrow{ }^{4} \mathrm{~T}_{1}$ transition is rising out of this structureless tail. Additional minor features present in each complex are the result of $d-d$ transitions within the pseudo-octahedral substituted metals, most obviously seen in $\mathbf{C o}^{\text {II }} \mathbf{V}^{\text {IV }}$ and $\mathbf{C o}^{\text {II }} \mathbf{F e}^{\text {III. }}$. The shape and peak energy of the d-d manifold stays roughly the same throughout the TMSP series, suggesting that any coupling to the substituted metal is weak or results in a uniform perturbation of the electronic structure of the $\mathrm{Co}^{\mathrm{II}}$ heteroatom.

A broad tail extending from the UV is assigned to $\mathrm{Co} \rightarrow \mathrm{W}$ (MPCT) transitions in each complex. Here each TMSP complex has a higher extinction coefficient than the plenary complex, with increases ranging from $18 \%$ to $500 \%$ at $400 \mathrm{~nm}$ (see Figure S3). This increase is most likely the result of $\mathrm{O} \rightarrow \mathrm{M}$ transitions introduced with the incorporated $3 \mathrm{~d}$ transition metal, though enhancement of the MPCT transition cannot be discounted. Additional anisotropy induced by the asymmetric polytungstate framework with a $3 \mathrm{~d}$ transition metal may result in a more intense MPCT band due to greater overlap between the ground and excited states, although interpretation of such broad absorption tails must be made with caution.

To explore the photodynamics of the MPCT excited state, it is important to consider whether the transition varies greatly upon substitution of the polytungstate framework such that another pump wavelength is necessary. The energy gap between the doubly-occupied oxygen orbitals and the empty tungsten orbitals upon substitution of the framework is relatively invariant. ${ }^{68,69}$ Likewise, the heteroatom within Keggin POMs is considered to be largely electronically isolated from the framework itself. ${ }^{64,70,71}$ Therefore, it is reasonable to assume, and is experimentally demonstrated (vide infra), that each TMSP complex possesses an MPCT transition within the absorption manifold at $\sim 400 \mathrm{~nm}$, the excitation wavelength used in our previous study. ${ }^{41}$ 


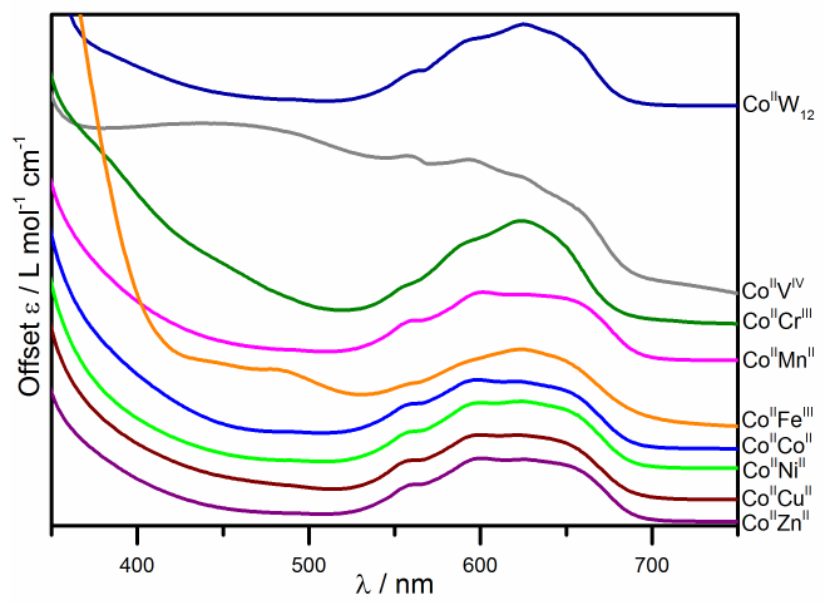

Figure 2. Offset visible electronic absorption spectra of the plenary Keggin POM $\mathrm{Co}^{\mathrm{II}} \mathrm{W}_{12}$ and eight TMSP derivatives in water. The spectra are offset to highlight the common feature at $\sim 625 \mathrm{~nm}$, assigned to the d-d transition of the tetrahedral $\mathrm{Co}^{\mathrm{II}}$ heteroatom.

Table 2. Comparison of electronic absorption spectra of TMSPs

\begin{tabular}{|l|l|l|}
\hline Complex & $\varepsilon_{400} / \mathrm{L} \mathrm{mol}^{-1} \mathrm{~cm}^{-1}$ & $\varepsilon_{625} / \mathrm{L} \mathrm{mol}^{-1} \mathrm{~cm}^{-1}$ \\
\hline $\mathrm{Co}^{\mathrm{II}} \mathrm{W}_{12}$ & 108 & 223 \\
\hline $\mathrm{Co}^{\mathrm{II}} \mathrm{V}^{\mathrm{IV}}$ & 543 & 405 \\
\hline $\mathrm{Co}^{\mathrm{II}} \mathrm{Cr}^{\mathrm{III}}$ & 359 & 285 \\
\hline $\mathrm{Co}^{\mathrm{II}} \mathrm{Mn}^{\mathrm{II}}$ & 164 & 183 \\
\hline $\mathrm{Co}^{\mathrm{II}} \mathrm{Fe}^{\mathrm{III}}$ & 384 & 233 \\
\hline $\mathrm{Co}^{\mathrm{II}} \mathrm{Co}^{\mathrm{II}}$ & 205 & 184 \\
\hline $\mathrm{Co}^{\mathrm{II}} \mathrm{Ni}^{\mathrm{II}}$ & 144 & 191 \\
\hline $\mathrm{Co}^{\mathrm{II}} \mathrm{Cu}^{\mathrm{II}}$ & 175 & 198 \\
\hline $\mathrm{Co}^{\mathrm{II}} \mathrm{Zn}^{\mathrm{II}}$ & 128 & 182 \\
\hline
\end{tabular}

Electrochemistry. Cyclic voltammetry was performed on each TMSP complex, the plenary $\mathbf{C o}^{\mathrm{II}} \mathbf{W}_{\mathbf{1 2}}$, and the lacunary TMSP-precursor $\mathbf{C o}^{\text {III }} \mathbf{W}_{\mathbf{1 1}}$ to evaluate the influence of the substituted transition metal on the redox behavior of the central cobalt heteroatom. Cyclic voltammograms for each complex were recorded in buffered solutions at $\mathrm{pH} \mathrm{5,} \mathrm{conditions} \mathrm{under} \mathrm{which} \mathrm{all} \mathrm{complexes} \mathrm{are} \mathrm{stable.} \mathrm{Full} \mathrm{cyclic}$ voltammograms, from oxidative $(+1.2 \mathrm{~V})$ to reductive $(-1.0 \mathrm{~V})$ potentials, were recorded (Figures S6 and S7), with all complexes exhibiting $\mathrm{pH}$-dependent multi-electron tungsten reduction peaks consistent with Keggin POMs $\left(\mathrm{E}_{1 / 2}\right.$ starting at $\left.\approx-500 \mathrm{mV}\right) .{ }^{72}$ In the case of $\mathbf{C} \mathbf{o}^{\mathrm{II}} \mathbf{C u} \mathbf{u}^{\mathrm{II}}$, applying a negative potential led to reduction of $\mathrm{Cu}^{\mathrm{II}}$ to $\mathrm{Cu}^{0}$ and subsequent extraction from the POM and deposition on the glassy carbon electrode. Due to the similarities between all reported TMSPs at reductive potentials, only the oxidative processes are discussed further.

An oxidative cyclic voltammogram for $\mathbf{C o}^{\text {II }} \mathbf{C o}{ }^{\text {II }}$, representative of the series, is shown in Figure 3 (summary values are provided in Table 3, and oxidative CVs for all other complexes are shown in Figures S4 and S5; full electrochemical measurements are tabulated in Table S3). Two pseudo-reversible redox 
processes are observed in $\mathbf{C o}^{\mathrm{II}} \mathbf{C o}^{\mathrm{II}}$ corresponding to the $\mathrm{Co}^{\mathrm{II} / I I I}$ couple for the central heteroatom $\left(\mathrm{E}_{1 / 2}=\right.$ $610 \mathrm{mV} ; \Delta \mathrm{E}=110 \mathrm{mV})$ and the addendum pseudo-octahedral cobalt $\left(\mathrm{E}_{1 / 2}=840 \mathrm{mV} ; \Delta \mathrm{E}=140 \mathrm{mV}\right)$, consistent with the central cobalt being oxidized at a lower potential than the substituted metal (vide supra). For comparison, the single reversible redox process observed in $\mathbf{C o}^{\mathbf{I I}} \mathbf{W}_{\mathbf{1 2}}$ is at a more oxidizing potential $\left(\mathrm{E}_{1 / 2}=870 \mathrm{mV} ; \Delta \mathrm{E}=70 \mathrm{mV}\right)$, and is nearly the same as that observed in $\mathbf{C o}^{\mathrm{III}} \mathbf{W}_{\mathbf{1 1}}$. This shift in the redox potential of the central heteroatom is consistent with the greater negative charge on the TMSP. ${ }^{72}$

Introduction of the addendum heterometal causes a significant shift $(\sim 250 \mathrm{mV})$ in the $\mathrm{Co}^{\mathrm{II} / \mathrm{III}}$ redox couple throughout most of the TMSP series. In all but two cases, substitution leads to small differences in the position of the central $\mathrm{Co}^{\mathrm{II} / \mathrm{III}}$ redox couple (all within a $40 \mathrm{mV}$ range). In $\mathbf{C o} \mathbf{o}^{\mathrm{II}} \mathbf{M n}^{\mathrm{II}}$, the observed peaks are separated by $300 \mathrm{mV}$ and their shapes are consistent with chemical reactions occurring within the timeframe of the electrochemical experiment. This behavior is very similar to the $\mathrm{pH}$-dependent behavior seen in $\left[\mathrm{SiMn}^{\mathrm{II}}\left(\mathrm{H}_{2} \mathrm{O}\right) \mathrm{W}_{11} \mathrm{O}_{39}\right]^{6-}$, an isostructural system, and is assigned to a combination of protonation and disproportionation reactions. ${ }^{73}$ In $\mathbf{C o}^{\mathrm{II}} \mathbf{Z n}^{\mathrm{II}}$, the $\mathrm{Co}^{\mathrm{II} / I I I}$ redox couple is observed at the same potential as in the plenary complex $\left(\mathrm{E}_{1 / 2}=880 \mathrm{mV} ; \Delta \mathrm{E}=80 \mathrm{mV}\right)$. This result suggests that the influence of a redox-active substituted metal causes the redox couple of the central $\mathrm{Co}^{\mathrm{II}}$ heteroatom to shift to lower potentials, irrespective of the negative charge on the complex. Therefore, these complexes narrow the difference in potential between the central heteroatom and the polytungstate framework, and the resulting red-shift in the MPCT transition is reflected in enhanced extinction coefficients at $400 \mathrm{~nm}$. Thus, the peak absorption of the MPCT transition can be tuned (vide infra).

The TMSP derivatives containing substituted redox active metals also exhibit redox couples associated with the addenda heteroatom, with the exception of $\mathbf{C o}^{\text {II }} \mathbf{M n}^{\text {II }}$ noted above, where chemical reactions obscure the Mn redox couple. $\mathbf{C o}^{\text {II }} \mathbf{V}^{\mathrm{IV}}\left(\mathrm{E}_{1 / 2}=270 \mathrm{mV} ; \Delta \mathrm{E}=90 \mathrm{mV}\right)$ and $\mathbf{C o}^{\mathrm{II}} \mathbf{F e}^{\mathrm{III}}\left(\mathrm{E}_{1 / 2}=-260 \mathrm{mV} ; \Delta \mathrm{E}=\right.$ $120 \mathrm{mV}$ ) both exhibit redox couples at more reducing potentials than the $\mathrm{Co}^{\mathrm{II} / \mathrm{III}}$ couple and are consistent with literature reports. ${ }^{45,72}$ Likewise, the addenda redox couple for $\mathbf{C o}^{\mathrm{II}} \mathbf{C o}^{\mathrm{II}}\left(\mathrm{E}_{1 / 2}=840 \mathrm{mV} ; \Delta \mathrm{E}=140\right.$ $\mathrm{mV})$ is consistent with earlier reports. ${ }^{42,43,74} \mathbf{C o}^{\mathrm{II}} \mathbf{C u}^{\mathrm{II}}$ exhibits a $\mathrm{Cu}^{\mathrm{I} / \mathrm{III}}$ redox couple $\left(\mathrm{E}_{1 / 2}=850 \mathrm{mV} ; \Delta \mathrm{E}=\right.$ $120 \mathrm{mV})$ as well as a more negative couple $\left(\mathrm{E}_{1 / 2}=-80 \mathrm{mV} ; \Delta \mathrm{E}=60 \mathrm{mV}\right)$ consistent with anodic stripping of $\mathrm{Cu}^{\mathrm{II}}$ to $\mathrm{Cu}^{0} .^{75}$ Interestingly, both $\mathrm{Co}^{\mathrm{II}} \mathbf{C r}^{\mathrm{III}}\left(\mathrm{E}_{1 / 2}=860 \mathrm{mV} ; \Delta \mathrm{E}=90 \mathrm{mV}\right)$ and $\mathbf{C o}^{\mathrm{II}} \mathbf{N i}^{\mathrm{II}}\left(\mathrm{E}_{1 / 2}=880 \mathrm{mV}\right.$; $\Delta \mathrm{E}=80 \mathrm{mV}$ ) exhibit redox couples associated with the substituted metal where an analogous TMSP series shows no electroactivity. ${ }^{75}$

Electrochemical measurements can be used to estimate the energy gap of the MPCT transition to consider whether a different pump wavelength is necessary, despite the transition being broad and obscured in the electronic absorption spectrum. The charge transfer transition of interest is between a filled $\mathrm{Co}_{\mathrm{Td}} e$ orbital and an empty tungsten orbital, $\mathrm{Co}_{\mathrm{e}} \rightarrow \mathrm{W}$. The total energy necessary to complete this transition is estimated as the sum of the energy gaps for $\mathrm{Co}_{e} \rightarrow \mathrm{Co}_{\mathrm{t} 2}$, the primary d-d transition, and $\mathrm{Co}_{\mathrm{t} 2} \rightarrow \mathrm{W}$, a lower energy MPCT approximated by the energy gap between the $\mathrm{Co}^{\mathrm{II} / \mathrm{III}}$ and the lowest $\mathrm{W}^{\mathrm{V} / \mathrm{VI}}$ redox couple (Table 3). The latter energy gap is $\sim 1.14 \pm 0.08 \mathrm{eV}$ for six of the substituted complexes, and increases to $1.38 \mathrm{eV}$ and $1.33 \mathrm{eV}$ for $\mathbf{C o}^{\text {II }} \mathbf{V}^{\text {IV }}$ and $\mathbf{C o}^{\mathbf{I}} \mathbf{Z n}^{\text {II }}$, respectively. The six complexes with the smallest energy gaps therefore give an MPCT transition energy of $3.13 \pm 0.08 \mathrm{eV}(398 \pm 10 \mathrm{~nm})$, while $\mathbf{C o}^{\text {II }} \mathbf{V}^{\text {IV }}$ and $\mathbf{C o}^{\text {II }} \mathbf{Z n}^{\text {II }}$, with the largest energy gaps, will exhibit an MPCT transition energy of $3.38 \mathrm{eV}(367 \mathrm{~nm})$ and $3.31 \mathrm{eV}$ $(375 \mathrm{~nm})$, respectively. In all cases, transition-metal substitution results in an estimated MPCT transition that is red-shifted relative to $\mathbf{C o}{ }^{\mathrm{II}} \mathbf{W}_{\mathbf{1 2}}(3.39 \mathrm{eV} ; 365 \mathrm{~nm})$, affording MPCT transitions close to the $400 \mathrm{~nm}$ excitation wavelength used to investigate them at an ultrafast timescale. Substitution of the polytungstate 
framework effectively tunes the peak absorption of the MPCT transition to longer wavelengths, possibly contributing to the increased absorption at $400 \mathrm{~nm}$ observed in the TMSP series.

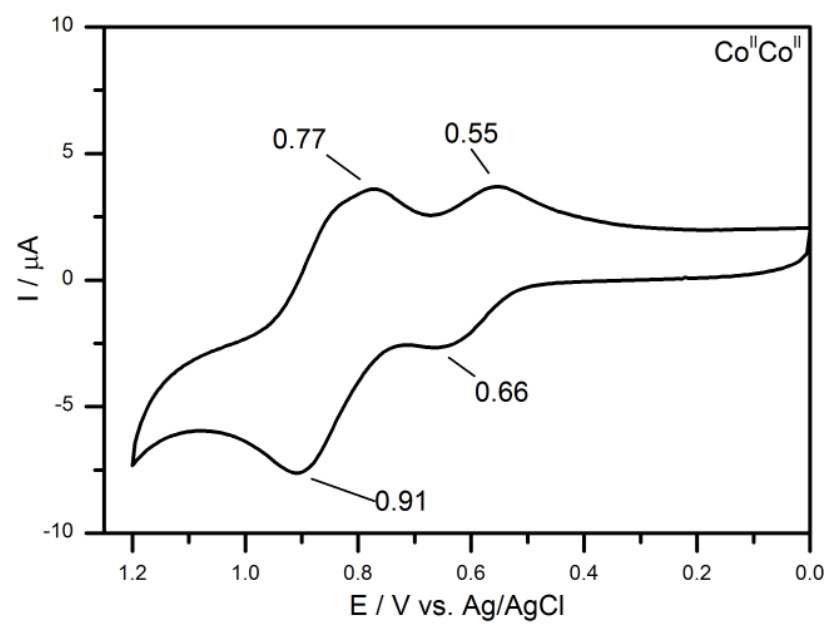

Figure 3. Oxidative cyclic voltammogram of $\sim 1 \mathrm{mM} \mathrm{Co}{ }^{\mathrm{II}} \mathrm{Co}^{\mathrm{II}}$ measured in $0.500 \mathrm{M}$ potassium acetate buffer, $\mathrm{pH} 5,50 \mathrm{mV} / \mathrm{s}$ scan rate. Resolved peaks are annotated.

Table 3. Summary of TMSP electrochemistry and estimated transition energies based on electronic absorption spectra and electrochemistry data

\begin{tabular}{|c|c|c|c|c|c|c|c|}
\hline \multirow[t]{2}{*}{ Complex } & $C o^{I I / I I I}$ & $M$ & $W_{l}$ & \multicolumn{3}{|c|}{ Transition energies / $\mathrm{eV}$} & $\mathrm{MPCT} / \mathrm{nm}$ \\
\hline & \multicolumn{3}{|c|}{$E_{1 / 2} / V$} & $C o_{t 2} \rightarrow W$ & $\mathrm{Co}_{e} \rightarrow \mathrm{Co}_{t 2} *$ & $C o_{e} \rightarrow W$ & $C o_{e} \rightarrow W$ \\
\hline $\mathrm{Co}^{\mathrm{II}} \mathrm{W}_{12}$ & 0.87 & - & -0.54 & 1.41 & 1.98 & 3.39 & 365 \\
\hline $\mathrm{Co}^{\mathrm{II}} \mathrm{V}^{\mathrm{IV}}$ & 0.65 & 0.27 & -0.73 & 1.38 & 2.00 & 3.38 & 367 \\
\hline $\mathrm{Co}^{\mathrm{II}} \mathrm{Cr}^{\mathrm{III}}$ & 0.64 & 0.86 & -0.53 & 1.17 & 1.99 & 3.16 & 392 \\
\hline $\mathrm{Co}^{\mathrm{II}} \mathrm{Mn}^{\mathrm{II}}$ & 0.75 & - & -0.45 & 1.21 & 1.99 & 3.20 & 388 \\
\hline $\mathrm{Co}^{\mathrm{II}} \mathrm{Fe}^{\mathrm{III}}$ & 0.62 & -0.26 & -0.57 & 1.18 & 1.99 & 3.17 & 391 \\
\hline $\mathrm{Co}^{\mathrm{II}} \mathrm{Co}^{\mathrm{II}}$ & 0.61 & 0.84 & -0.45 & 1.06 & 1.99 & 3.05 & 407 \\
\hline $\mathrm{Co}^{\mathrm{II}} \mathrm{Ni}^{\mathrm{II}}$ & 0.61 & 0.88 & -0.46 & 1.07 & 1.99 & 3.05 & 406 \\
\hline $\mathrm{Co}^{\mathrm{II}} \mathrm{Cu}^{\mathrm{II}}$ & 0.61 & 0.85 & -0.45 & 1.07 & 1.99 & 3.06 & 405 \\
\hline $\mathrm{Co}^{\mathrm{II}} \mathrm{Zn}^{\mathrm{II}}$ & 0.88 & - & -0.45 & 1.33 & 1.98 & 3.31 & 375 \\
\hline
\end{tabular}

$*$ The wavelength used for $\mathrm{Co}_{\mathrm{e}} \rightarrow \mathrm{Co}_{\mathrm{t} 2}$ was typically the $\lambda_{\max }$ for each complex, except in cases where the $\lambda_{\max }$ did not represent the approximate center of the $\mathrm{d}$-d manifold. In those cases a wavelength was selected among the visible multiplets.

Transient Absorption Spectra and Kinetics. Ultrafast measurements of each TMSP complex and the plenary Co $\mathbf{C o}^{\text {II }} \mathbf{W}_{12}$ were recorded under identical conditions (buffered solution, pump power, probe power) for direct comparison of the photodynamics of the MPCT excited state. The transient absorption spectra 
and kinetics for $\mathbf{C o}{ }^{\text {II }} \mathbf{C o}^{\text {II }}$, representative of the entire series, are shown in Figure 4. The transient spectra and kinetics for all complexes exhibit nearly identical features to those for $\mathbf{C o}^{\mathrm{II}} \mathbf{C o}^{\mathrm{II}}$ and are strongly reminiscent of the excited state dynamics of $\mathbf{C o}^{\mathrm{II}} \mathbf{W}_{\mathbf{1 2}}$, also reproduced here for comparison (Figure S8; remaining TMSP derivatives in Figures S8 and S9).

The photodynamics of $\mathbf{C o}^{\mathbf{I I}} \mathbf{W}_{\mathbf{1 2}}$ are extensively discussed in our previous report; ${ }^{41}$ a brief description of its features and comparison to the derivative TMSP series is given here. Following excitation at $400 \mathrm{~nm}$, $\mathbf{C o}^{\text {II }} \mathbf{C o}^{\text {II }}$ produces a broad, intense absorption feature consistent with a heteropoly blue excited state. The initial state decays rapidly to a second excited state with a ground state bleach centered at $625 \mathrm{~nm}$ and absorption bands at higher and lower energies. These features are indicative of an excited state in which an electron has been photoexcited from the tetrahedral $\mathrm{Co}^{\mathrm{II}}$ heteroatom to empty orbital(s) located within the polytungstate framework, and are very similar to those of $\mathbf{C o}{ }^{\text {II }} \mathbf{W}_{\mathbf{1 2}}$. The transient absorption spectra for the other TMSP complexes reveal similar results. In each case, the initial excited state $\left(\tau_{1}\right)$ decays rapidly to the second excited state $\left(\tau_{2}\right)$ bearing features of the MPCT transition. Importantly, differences in the shape of the ground state bleach between the different compounds correspond to changes in the d-d manifold present in static electronic absorption spectra, confirming that the bleach always has the same origin.

Notably, however the lifetimes for both the initial $\left(\tau_{1}=440 \pm 330 \mathrm{fs}\right)$ and second excited states $\left(\tau_{2}=120\right.$ \pm 44 ps) of $\mathbf{C o}^{\mathrm{II}} \mathbf{C o} \mathbf{o}^{\mathrm{II}}$ are considerably shorter than for $\mathbf{C o}^{\mathrm{II}} \mathbf{W}_{\mathbf{1 2}}$, with time constants that are $54 \%$ and $72 \%$ shorter, respectively. Indeed, in all eight TMSPs, both excited states decay at a faster rate than in the plenary complex (Figure 5 and Table 4), suggesting that substitution of $[\mathrm{W}=\mathrm{O}]^{4+}$ with $\left[\mathrm{M}-\mathrm{OH}_{2}\right]^{2+},[\mathrm{M}-$ $\left.\mathrm{OH}_{2}\right]^{3+}$ or $[\mathrm{V}=\mathrm{O}]^{2+}$ introduces additional (or accelerates existing) deactivation pathways. While we are yet to find an unambiguous relationship between the excited state lifetimes of these species and any single aspect of the anion structures, we can identify several factors that likely influence $\tau_{1}$ and $\tau_{2}$. First, deactivation of the excited state will be strongly affected by the interaction of the anion with its environment (solvent and cations). In all of the TMSPs but $\mathbf{C o}^{\mathrm{II}} \mathbf{V}^{\mathrm{IV}}$, the presence of a labile aqua ligand likely provides additional vibrational relaxation pathways to shorten both $\tau_{1}$ and $\tau_{2} .{ }^{76-81}$ Moreover, the increased charge on the anions vs. $\mathbf{C o}^{\mathrm{II}} \mathbf{W}_{\mathbf{1 2}}$ (from 6- to 7-/8-) will give rise to increased ion pairing. This is known to stabilize CT excited states, and reduce excited state lifetimes in accord with the energy gap law: ${ }^{82}$ note that in the case of $\mathbf{C o}{ }^{\text {II }} \mathbf{W}_{\mathbf{1 2}}$ moving to a less polar medium was seen to dramatically increase $\tau_{2}{ }^{41}$ Within the anions, the presence of orbitals at energies intermediate between the tetrahedral Co $t_{2}$ level and the $\mathrm{W}$ acceptor orbitals should also lead to shorter excited state lifetimes by the energy gap law ${ }^{83-88}$ - electrochemical measurements and/or DFT calculations indicate that this situation is pertinent in $\mathbf{C o}^{\text {II }}{ }^{\text {IV }}, \mathbf{C o}^{\text {II }} \mathbf{M n}^{\text {II }}$, and $\mathbf{C o}^{\text {II }} \mathbf{F e} e^{\text {III }}$. In the case of $\mathbf{C o}^{\text {II }} \mathbf{M n}^{\text {II }}$ and $\mathbf{C o}^{\text {II }}{ }^{\text {IV }}$, this intermediate energy level is occupied by an electron which could be transferred to $\mathbf{C o}^{\mathrm{III}}$ upon formation of the MPCT excited state.

Bearing these factors in mind, it is interesting to note that the two longest-lived $\tau_{2}$ excited states $(270 \pm 15$ and $220 \pm 31$ ps respectively for $\mathbf{C o}^{\mathrm{II}} \mathbf{C r}^{\mathrm{III}}$ and $\mathbf{C o}^{\mathrm{II}} \mathbf{F e}^{\mathrm{III}}$ ) are observed in the two least charged anions (both 7-), and the difference in lifetime between these two, albeit almost within experimental error, is consistent with the presence of the lower lying energy level (smaller energy gap) provided by $\mathrm{Fe}^{\mathrm{II} / \mathrm{II}}$ in this system. Of the other six anions (all 8-), all but $\mathbf{C o}^{\mathrm{II}} \mathbf{N i}{ }^{\mathrm{II}}$ have $\tau_{2}$ of $c a .100 \mathrm{ps}$, and within the experimental error from one another, meaning that it is not possible to confidently discern an influence for either terminal ligand (oxo $v s$ aqua) or intermediate energy levels (present in $\mathbf{C o}^{\mathbf{I I}} \mathbf{M} \mathbf{n}^{\mathbf{I I}}$ and $\mathbf{C o}^{\mathbf{I I}} \mathbf{V}^{\mathbf{I V}}$ ) in this series. Furthermore, the slight increase in $\tau_{2}$ seen for $\mathbf{C o}{ }^{\mathrm{II}} \mathbf{N i}^{\mathbf{I I}}$ does not correlate with the estimated 
extent of Co-M electronic coupling estimated from calculated one-electron oxidation potentials (vide supra), although it may relate to nickel's increased preference for square planar coordination. This would reduce the strength of interaction with the aqua ligand and the $\mathrm{O}^{1}$ bridge to Co. Overall, from this study and our previous work, ${ }^{41}$ it seems that the dominant influences on excited state lifetimes in these systems are the location of the CT donor atom, and the strength of interaction between the anion and the medium.
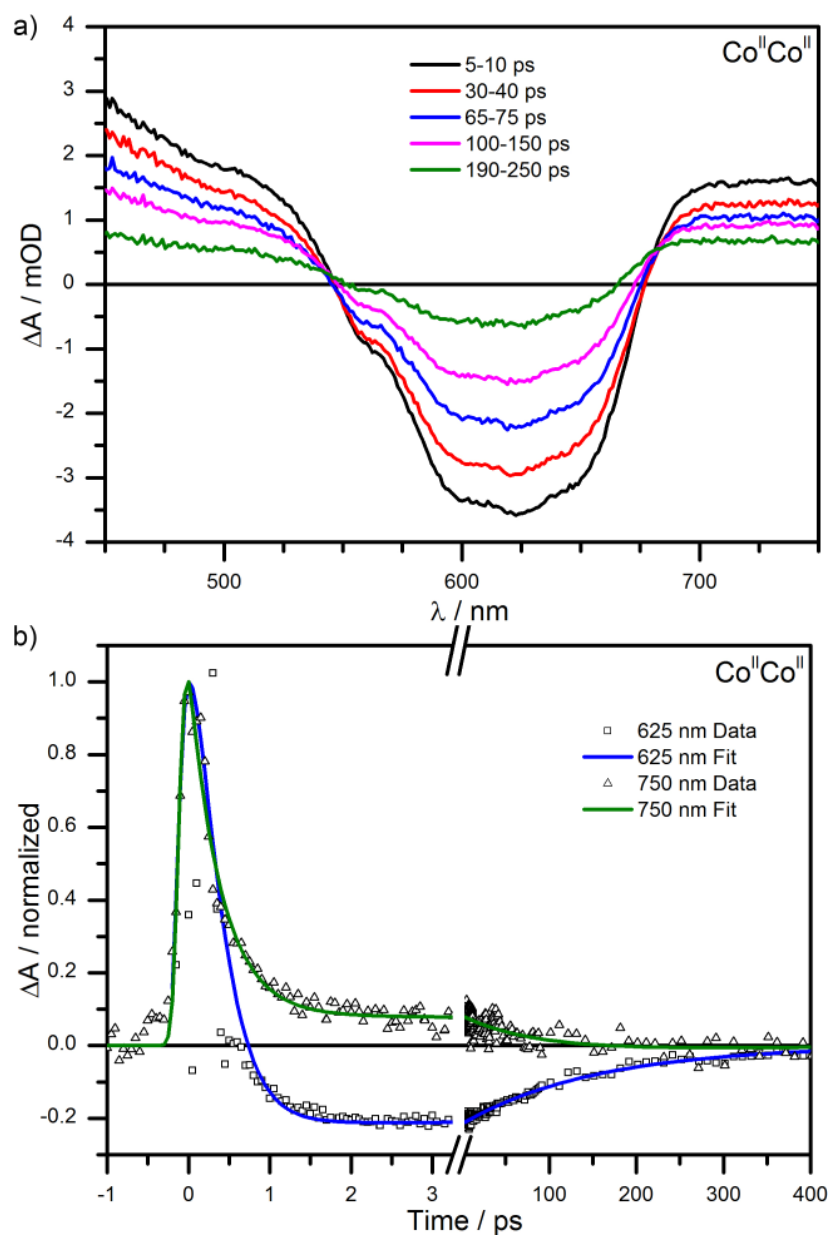

Figure 4. Transient absorption spectra and kinetics of $\mathrm{Co}^{\mathrm{II}} \mathrm{Co}^{\mathrm{II}}$ after excitation by an ultrafast pump pulse at $400 \mathrm{~nm}$. Spectral traces are the average of multiple measurements within the noted time windows. Empirical measurements and multiexponential fits to the kinetics at two wavelengths are shown normalized to their respective peak values. Solvent conditions (0.250 M LiAc buffer, pH 5) and pump power were kept consistent between measurements of all compounds. 

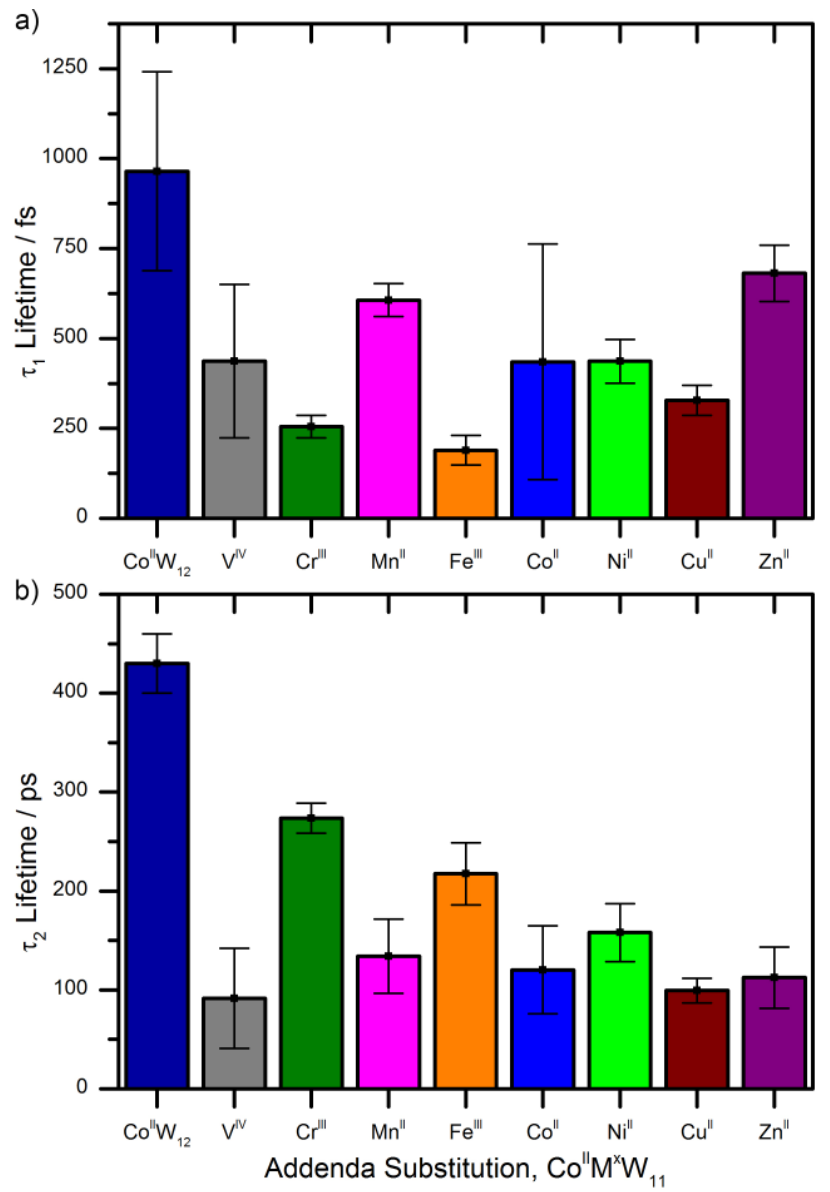

Figure 5. Comparison of the a) first and b) second excited state exponential lifetimes for the plenary POM complex $\mathrm{Co}^{\mathrm{II}} \mathrm{W}_{12}$ and its eight TMSP derivatives upon excitation by an ultrafast pump pulse at 400 $\mathrm{nm}$. Solvent conditions ( $0.250 \mathrm{M} \mathrm{LiAc}$ buffer, $\mathrm{pH}$ 5) and pump power were kept consistent between measurements. Error bars represent the $95 \%$ confidence interval for each lifetime, calculated by global fit analysis.

Table 4. Multi-exponential lifetimes of transient absorption spectra

\begin{tabular}{|l|l|l|}
\hline Complex & \multicolumn{2}{|c|}{ Lifetimes } \\
\hline & $\tau_{1} / \mathrm{fs}$ & $\tau_{2} / \mathrm{ps}$ \\
\hline $\mathrm{Co}^{\mathrm{II}} \mathrm{W}_{12}$ & $960 \pm 280$ & $430 \pm 30$ \\
\hline $\mathrm{Co}^{\mathrm{II}} \mathrm{V}^{\mathrm{IV}}$ & $440 \pm 210$ & $91 \pm 50$ \\
\hline $\mathrm{Co}^{\mathrm{II}} \mathrm{Cr}^{\mathrm{III}}$ & $260 \pm 30$ & $270 \pm 15$ \\
\hline $\mathrm{Co}^{\mathrm{II}} \mathrm{Mn}^{\mathrm{II}}$ & $610 \pm 50$ & $130 \pm 37$ \\
\hline $\mathrm{Co}^{\mathrm{II}} \mathrm{Fe}^{\mathrm{III}}$ & $190 \pm 40$ & $220 \pm 31$ \\
\hline $\mathrm{Co}^{\mathrm{II}} \mathrm{Co}^{\mathrm{II}}$ & $440 \pm 330$ & $120 \pm 44$ \\
\hline $\mathrm{Co}^{\mathrm{II}} \mathrm{Ni}^{\mathrm{II}}$ & $440 \pm 60$ & $160 \pm 29$ \\
\hline $\mathrm{Co}^{\mathrm{II}} \mathrm{Cu}^{\mathrm{II}}$ & $330 \pm 40$ & $99 \pm 12$ \\
\hline $\mathrm{Co}^{\mathrm{II}} \mathrm{Zn}^{\mathrm{II}}$ & $680 \pm 80$ & $110 \pm 31$ \\
\hline
\end{tabular}




\section{Conclusions}

A series of heterobimetallic TMSPs containing redox-active 3d-electrons, $\left[\mathrm{Co}^{\mathrm{II}}\left(\mathrm{M}^{\mathrm{x}} \mathrm{OH}_{\mathrm{y}}\right) \mathrm{W}_{11} \mathrm{O}_{39}\right]^{(12-\mathrm{x}-\mathrm{y}) \text { - }}$ $\left(\mathrm{M}^{\mathrm{x}} \mathrm{OH}_{\mathrm{y}}=\mathrm{V}^{\mathrm{IV}} \mathrm{O}, \mathrm{Cr}^{\mathrm{III}}\left(\mathrm{OH}_{2}\right), \mathrm{Mn}^{\mathrm{II}}\left(\mathrm{OH}_{2}\right), \mathrm{Fe}^{\mathrm{III}}\left(\mathrm{OH}_{2}\right), \mathrm{Co}^{\mathrm{II}}\left(\mathrm{OH}_{2}\right), \mathrm{Ni}^{\mathrm{II}}\left(\mathrm{OH}_{2}\right), \mathrm{Cu}^{\mathrm{II}}\left(\mathrm{OH}_{2}\right), \mathrm{Zn}^{\mathrm{II}}\left(\mathrm{OH}_{2}\right)\right)$ have been synthesized and their photodynamics investigated. All complexes within the series have a demonstrated MPCT transition between the central cobalt heteroatom and the polytungstate framework, analogous to their plenary parent complex. Transition metal substitution of the polytungstate framework leads to significant changes in the electrochemical properties and red-shifting of the MPCT transition. In all cases, transition metal substitution leads to a decrease in the lifetimes of the MPCT excited state, but increases in absorption, with the $\mathrm{Cr}$ - and $\mathrm{Fe}$-substituted systems apparently offering a reasonable compromise between significantly ( $3 \mathrm{x}$ or more) increased visible light absorption and excited state lifetimes $>50 \%$ that of $\left[\mathrm{Co}^{\mathrm{II}} \mathrm{W}_{12} \mathrm{O}_{40}\right]^{6-}$. The decreased lifetimes are most likely due to nonradiative relaxation due to coordinating aqua ligands, and increased ion pairing (increased charge) that stabilizes CT excited states and reduces lifetimes by the energy gap law. Combined with our previous studies, this appears to indicate that the most promising avenue to increase MPCT lifetimes is to weaken the interaction of the POM framework with solvent and counter cations, while stronger visible absorption should be achieved through the use of $4^{\text {th }}$ and $5^{\text {th }}$ row elements as donor atoms.

\section{Associated Content}

\section{Supporting Information}

Crystallographic data and statistics, an ORTEP representation and tabulated bond lengths and angles for Co' Co ${ }^{\text {II }}$, infrared spectra, overlaid visible electronic spectra, electrochemical data, cyclic voltammograms, transient absorption spectra, and thermogravimetric analyses for all compounds, and full calculated geometries for all reported TMSPs at their lower-lying electronic states. This material is available free of charge via the Internet at http://pubs.acs.org.

\section{Author Information}

\section{Corresponding Author}

*E-mail: chill@emory.edu (C.L.H.)

\section{Present Address}

\section{Notes}

The authors declare no competing financial interest.

\section{Acknowledgments}

This material is based upon work supported by the U.S. Department of Energy, Office of Science, Office of Basic Energy Sciences, Solar Photochemistry Program under Award Number DE-FG02-07ER15906. The authors gratefully acknowledge NSF MRI-R2 grant (CHE-0958205) and the use of the resources of the Cherry Emerson Center for Scientific Computation. J.F. is supported by a Marie Curie International 
Outgoing Fellowship (POMHYDCAT, contract no. 254339) within the 7th European Union Framework Programme. X.X. thanks the China Scholarship Council and NSDC (\#21376020) for financial support.

\section{References}

(1) Urbani, M.; Grätzel, M.; Nazeeruddin, M. K.; Torres, T. s. Chem. Rev. 2014, 114, 12330.

(2) Yum, J.-H.; Baranoff, E.; Wenger, S.; Nazeeruddin, M. K.; Grätzel, M. Energy Environ. Sci. $2011,4,842$.

(3) Hagfeldt, A.; Boschloo, G.; Sun, L.; Kloo, L.; Pettersson, H. Chem. Rev. 2010, 110, 6595.

(4) Kanan, M. W.; Nocera, D. G. Science 2008, 321, 1072.

(5) Youngblood, W. J.; Lee, S.-H. A.; Maeda, K.; Mallouk, T. E. Acc. Chem. Res. 2009, 42,

1966.

(6) Barnett, S. M.; Goldberg, K. I.; Mayer, J. M. Nat. Chem. 2012, 4, 498.

(7) Yin, Q.; Tan, J. M.; Besson, C.; Geletii, Y. V.; Musaev, D. G.; Kuznetsov, A. E.; Luo, Z.; Hardcastle, K. I.; Hill, C. L. Science 2010, 328, 342.

(8) Geletii, Y. V.; Botar, B.; Kögerler, P.; Hillesheim, D. A.; Musaev, D. G.; Hill, C. L. Angew. Chem. Int. Ed. 2008, 47, 3896.

(9) Lv, H.; Song, J.; Geletii, Y. V.; Vickers, J. W.; Sumliner, J. M.; Musaev, D. G.; Kögerler, P.; Zhuk, P. F.; Bacsa, J.; Zhu, G.; Hill, C. L. J. Am. Chem. Soc. 2014, 136, 9268.

(10) Helm, M. L.; Stewart, M. P.; Bullock, R. M.; DuBois, M. R.; DuBois, D. L. Science 2011, $333,863$.

(11) Du, P.; Schneider, J.; Jarosz, P.; Eisenberg, R. J. Am. Chem. Soc. 2006, 128, 7726.

(12) Morris, A. J.; McGibbon, R. T.; Bocarsly, A. B. ChemSusChem 2011, 4, 191.

(13) Kumar, B.; Smieja, J. M.; Kubiak, C. P. J. Phys. Chem. C 2010, 114, 14220.

(14) Ischay, M. A.; Anzovino, M. E.; Du, J.; Yoon, T. P. J. Am. Chem. Soc 2008, 130, 12886.

(15) Meng, Q.-Y.; Zhong, J.-J.; Liu, Q.; Gao, X.-W.; Zhang, H.-H.; Lei, T.; Li, Z.-J.; Feng, K.; Chen, B.; Tung, C.-H.; Wu, L.-Z. J. Am. Chem. Soc 2013, 135, 19052.

(16) Kuzyk, M. G. J. Mater. Chem. 2009, 19, 7444.

(17) Marder, S. R. Chem. Commun. 2006, 131.

(18) Coe, B. J. Acc. Chem. Res. 2006, 39, 383.

(19) Chen, W.-C.; Lee, C.-S.; Tong, Q.-X. J. Mater. Chem. C 2015, 3, 10957.

(20) Yang, X.; Zhou, G.; Wong, W.-Y. Chem. Soc. Rev. 2015, 44, 8484.

(21) You, Y.; Nam, W. Chem. Soc. Rev. 2012, 41, 7061.

(22) Lo, K. K.-W. Acc. Chem. Res. 2015, 48, 2985.

(23) Langton, M. J.; Marques, I.; Robinson, S. W.; Félix, V.; D.Beer, P. Chem. Eur. J. 2016, 22,

185.

(24) Ghosh, P. K.; Brunschwig, B. S.; Chou, M.; Creutz, C.; Sutin, N. J. Am. Chem. Soc. 1984, $106,4772$.

(25) Lin, W.; Frei, H. J. Am. Chem. Soc. 2005, 127, 1610.

(26) Lin, W.; Frei, H. J. Phys. Chem. B 2005, 109, 4929.

(27) Han, H.; Frei, H. J. Phys. Chem. C 2008, 112, 16156.

(28) Han, H.; Frei, H. J. Phys. Chem. C 2008, 112, 8391.

(29) Wu, X.; Weare, W. W.; Frei, H. Dalton Trans. 2009, 10114.

(30) Cuk, T.; Weare, W. W.; Frei, H. J. Phys. Chem. C 2010, 114, 9167.

(31) Takashima, T.; Yamaguchi, A.; Hashimoto, K.; Nakamura, R. Chem. Commun. 2012, 48, 2964.

(32) Takashima, T.; Nakamura, R.; Hashimoto, K. J. Phys. Chem. C 2009, 113, 17247. 
(33) Choing, S. N.; Francis, A. J.; Clendenning, G.; Schuurman, M. S.; Sommer, R. D.; Tamblyn, I.; Weare, W. W.; Cuk, T. J. Phys. Chem. C 2015, 119, 17029.

(34) Weare, W. W.; Pushkar, Y.; Yachandra, V. K.; Frei, H. J. Am. Chem. Soc 2008, 130, 13555.

(35) Wu, X.; Huang, T.; Lekich, T. T.; Sommer, R. D.; Weare, W. W. Inorg. Chem. 2015, 54,

5322.

(36) Zhao, C.; Huang, Z.; Rodríguez-Córdoba, W.; Kambara, C. S.; O’Halloran, K. P.;

Hardcastle, K. I.; Musaev, D. G.; Lian, T.; Hill, C. L. J. Am. Chem. Soc. 2011, 133, 20134.

(37) Zhao, C.; Rodríguez-Córdoba, W.; Kaledin, A. L.; Yang, Y.; Geletii, Y. V.; Lian, T.; Musaev, D. G.; Hill, C. L. Inorg. Chem. 2013, 52, 13490.

(38) Zhao, C.; Kambara, C. S.; Yang, Y.; Kaledin, A. L.; Musaev, D. G.; Lian, T.; Hill, C. L. Inorg. Chem. 2013, 52, 671.

(39) Zhao, C.; Glass, E. N.; Sumliner, J. M.; Bacsa, J.; Kim, D. T.; Guo, W.; Hill, C. L. Dalton Trans. 2014, 43, 4040.

(40) Zhao, C.; Glass, E. N.; Chica, B.; Musaev, D. G.; Sumliner, J. M.; Dyer, R. B.; Lian, T.; Hill, C. L. J. Am. Chem. Soc. 2014, 136, 12085.

(41) Glass, E. N.; Fielden, J.; Kaledin, A. L.; Musaev, D. G.; Lian, T.; Hill, C. L. Chem.- Eur. J. 2014, 20, 4297.

(42) Baker, L. C. W.; McCutcheon, T. P. J. Am. Chem. Soc. 1956, 78, 4503.

(43) Simmons, V. E. Ph.D. Dissertation, Boston University, 1953.

(44) Nolan, A. L.; Burns, R. C.; Lawrance, G. A. J. Chem. Soc., Dalton Trans. 1998, 3041.

(45) Bas-Serra, J.; Todorut, I.; Casañ-Pastor, N.; Server-Carrio, J.; Baker, L. C. W.; Acerete, R. Synth. React. Inorg. Met.-Org. Chem. 1995, 25, 869.

(46) Geletii, Y. V.; Bailey, A. J.; Boring, E.; Hill, C. L. J. Chem. Soc., Chem. Commun. 2001, 2001, 1484.

(47) APEXII (Version 2.0-1), SAINT (Version 7.23A) and SADABS (Version 2004/1), Bruker AXS, Inc., Madison, WI, USA, 2005.

(48) Coppens, P.; Leiserowitz, L.; Rabinovich, D. Acta Crystallogr. 1965, 18, 1035.

(49) SHELXTL (v 6.1), Bruker AXS, Inc., Madison, WI, USA, 2000.

(50) Becke, A. D. Phys. Rev. A 1988, 38, 3098.

(51) Lee, C.; Yang, W.; Parr, R. G. Phys. Rev. B 1988, 37, 785.

(52) Becke, A. D. J. Chem. Phys. 1993, 98, 5648.

(53) Ditchfield, R.; Hehre, W. J.; Pople, J. A. J. Chem. Phys. 1971, 54, 724.

(54) Hehre, W. J.; Ditchfield, R.; Pople, J. A. J. Chem. Phys. 1972, 56, 2257.

(55) Hay, P. J.; Wadt, W. R. J. Chem. Phys. 1985, 82, 270.

(56) Wadt, W. R.; Hay, P. J. J. Chem. Phys. 1985, 82, 284.

(57) Hay, P. J.; Wadt, W. R. J. Chem. Phys. 1985, 82, 299.

(58) Rappe, A. K.; Casewit, C. J.; Colwell, K. S.; Goddard, W. A.; Skiff, W. M. J. Am. Chem. Soc. 1992, 114, 10024.

(59) Tomasi, J.; Mennucci, B.; Cammi, R. Chem. Rev. 2005, 105, 2999.

(60) Frisch, M. J.; Trucks, G. W.; Schlegel, H. B.; Scuseria, G. E.; Robb, M. A.; Cheeseman, J. R.; Scalmani, G.; Barone, V.; Mennucci, B.; Petersson, G. A.; Nakatsuji, H.; Caricato, M.; Li, X.; Hratchian, H. P.; Izmaylov, A. F.; Bloino, J.; Zheng, G.; Sonnenberg, J. L.; Hada, M.; Ehara, M.; Toyota, K.; Fukuda, R.; Hasegawa, J.; Ishida, M.; Nakajima, T.; Honda, Y.; Kitao, O.; Nakai, H.; Vreven, T.; J. A. Montgomery, J.; Peralta, J. E.; Ogliaro, F.; Bearpark, M.; Heyd, J. J.; Brothers, E.; Kudin, K. N.; Staroverov, V. N.; Kobayashi, R.; Normand, J.; Raghavachari, K.; Rendell, A.; Burant, J. C.; Iyengar, S. S.; Tomasi, J.; Cossi, M.; N. Rega, J. M. M.; Klene, M.; Knox, J. E.; Cross, J. B.; Bakken, V.; Adamo, C.; Jaramillo, J.; Gomperts, R.; Stratmann, R. E.; Yazyev, O.; Austin, A. J.; Cammi, R.; Pomelli, C.; Ochterski, J. W.; Martin, R. L.; K. Morokuma, V. G. Z.; 
Voth, G. A.; Salvador, P.; Dannenberg, J. J.; Dapprich, S.; Daniels, A. D.; Ö. Farkas, J. B. F.; Ortiz, J. V.; Cioslowski, J.; Fox, D. J.; Revision C.01 ed.; Gaussian, I., Ed. Wallingford CT., 2009.

(61) Song, F.; Ding, Y.; Ma, B.; Wang, C.; Wang, Q.; Du, X.; Fu, S.; Song, J. Energy Environ. Sci. 2013, 6, 1170.

(62) Muncaster, G.; Sankar, G.; Catlow, C. R. A.; Thomas, J. M.; Coles, S. J.; Hursthouse, M. Chem. Mater. 2000, 16.

(63) Nolan, A. L.; Allen, C. C.; Burns, R. C.; Craig, D. C.; Lawrance, G. A. Aust. J. Chem. 2000, 53,59

(64) Casan-Pastor, N.; Gomez-Romero, P.; Jameson, G. B.; Baker, L. C. W. J. Am. Chem. Soc. $1991,113,5658$.

(65) Our calculations of the $\left[\mathrm{CoFe}\left(\mathrm{H}_{2} \mathrm{O}\right) \mathrm{W}_{11} \mathrm{O}_{39}\right]^{7-}$ anion converged to its [ $\mathrm{Co} \mathrm{O}^{\text {III }} \mathrm{Fe}$ "] state with four $\alpha$-spins on both Fe- and Co-centers, not the [Co" $\left.\mathrm{Ce}^{\prime \prime \prime}\right]$ state expected based on experimental techniques. The [Co"Fe"l'] state, which is expected to be only slightly (less than $1.0 \mathrm{kcal} / \mathrm{mol}$ ) higher in energy, cannot be calculated at the DFT level. Therefore, in our estimation of the one-electron oxidation energy for the $\left[\mathrm{CoFe}\left(\mathrm{H}_{2} \mathrm{O}\right) \mathrm{W}_{11} \mathrm{O}_{39}\right]^{7-}$ anion we used the energetically lowest [ $\left.\mathrm{Co}^{\prime \prime \prime} \mathrm{Fe} \mathrm{C}^{\prime \prime}\right]$ state.

(66) Rocchiccioli-Deltcheff, C.; Thouvenot, R. J. Chem. Res., Synop. 1977, 2, 46.

(67) Rocchiccioli-Deltcheff, C.; Thouvenot, R.; Franck, R. Spectrochim. Acta 1976, 32A, 587.

(68) Maestre, J. M.; López, X.; Bo, C.; Daul, C.; Poblet, J.-M. Inorg. Chem. 2002, 41, 1883.

(69) Maestre, J. M.; López, X.; Bo, C.; Poblet, J.-M.; Casañ-Pastor, N. J. Am. Chem. Soc. 2001, $123,3749$.

(70) Varga, G. M.; Papaconstantinou, E.; Pope, M. T. Inorg. Chem. 1970, 9, 662.

(71) Weinstock, I. A. Chem. Rev. 1998, 98, 113.

(72) Sadakane, M.; Steckhan, E. Chem. Rev. 1998, 98, 219.

(73) Müller, A.; Dloczik, L.; Diemann, E.; Pope, M. T. Inorg. Chim. Acta 1997, 257, 231.

(74) Baker, L. C. W.; Simmons, V. E. J. Am. Chem. Soc. 1959, 81, 4744.

(75) Cheng, L.; Sun, H.; Liu, B.; Liu, J.; Dong, S. J. Chem. Soc., Dalton Trans. 1999, 2619.

(76) Meshkova, S. B.; Topilova, Z. M.; Lozinskii, M. O.; Bol'shoi, D. V. J. Appl. Spectrosc. 1997, 64, 229.

(77) Moriyasu, M.; Yokoyama, Y.; Ikeda, S. J. Inorg. Nucl. Chem. 1977, 39, 2211.

(78) Bhaumik, M. L.; Nugent, L. J. J. Chem. Phys. 1965, 43, 1680.

(79) Hehlen, M. P.; Riesen, H.; Guedel, H. U. Inorg. Chem. 1991, 30, 2273.

(80) Dong, H.; Wheeler, R. A. Chem. Phys. Lett. 2005, 413, 176.

(81) Pavlovich, V. S. ChemPhysChem 2012, 13, 4081.

(82) Vining, W. J.; Caspar, J. V.; Meyer, T. J. J. Phys. Chem. 1985, 89, 1095.

(83) Englman, R.; Jortner, J. Mol. Phys. 1970, 18, 145.

(84) Freed, K. F.; Jortner, J. J. Chem. Phys. 1970, 52, 6272.

(85) Bixon, M.; Jortner, J. J. Chem. Phys. 1968, 48, 715.

(86) Caspar, J. V.; Kober, E. M.; Sullivan, B. P.; Meyer, T. J. J. Am. Chem. Soc. 1982, 104, 630.

(87) Robinson, G. W.; Frosch, R. P. J. Chem. Phys. 1963, 38, 1187.

(88) Bixon, M.; Jortner, J.; Cortes, J.; Heitele, H.; Michel-Beyerle, M. E. J. Phys. Chem. 1994, $98,7289$. 
Table of Contents Graphic

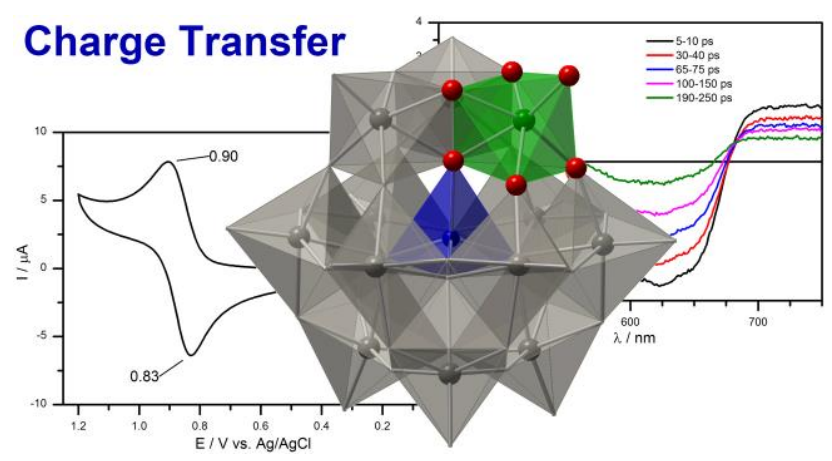

Table of Contents Synopsis

Electrochemistry, DFT calculations and ultrafast photophysics on the $\left[\mathrm{Co}^{\mathrm{II}}\left(\mathrm{M}^{\mathrm{x}} \mathrm{OH}_{\mathrm{y}}\right) \mathrm{W}_{11} \mathrm{O}_{39}\right]^{(12-\mathrm{x}-\mathrm{y})-}$ series of Keggin polyoxometalates show that compared to $\left[\mathrm{Co}^{\mathrm{II}} \mathrm{W}_{12} \mathrm{O}_{40}\right]^{6-}$, transition metal substitution red shifts the metal-to-polyoxometalate charge transfer (MPCT) transition and enhances visible light absorption, but decreases MPCT excited state lifetimes. 